Portland State University

PDXScholar

$1-1-2011$

Health Care Migration in Japan: Immigration Policy in Terms of Language

Ayumi Susai

Portland State University

Follow this and additional works at: https://pdxscholar.library.pdx.edu/open_access_etds Let us know how access to this document benefits you.

Recommended Citation

Susai, Ayumi, "Health Care Migration in Japan: Immigration Policy in Terms of Language" (2011). Dissertations and Theses. Paper 190.

https://doi.org/10.15760/etd.190

This Thesis is brought to you for free and open access. It has been accepted for inclusion in Dissertations and Theses by an authorized administrator of PDXScholar. Please contact us if we can make this document more accessible: pdxscholar@pdx.edu. 


\section{Health Care Migration in Japan}

\section{Immigration Policy in Terms of Language}

\section{By}

\section{Ayumi Susai}

A thesis submitted in partial fulfillment of the requirements for the degree of

\section{Master of Arts}

in

\section{Foreign Languages: Japanese}

Thesis Committee:

Patricia J. Wetzel, Chair

Laurence R. Kominz

Suwako Watanabe

Portland State University

(C) 2011 


\begin{abstract}
This thesis argues the necessity of new standards for Japanese language teaching in Japan, responding to diversifying social needs. The current situation for foreign workers in Japan is a pressing issue in the light of declining fertility rates and a rapidly aging population. The focus of chapter 1 is this paper particularly focuses on issues regarding acceptance of nurses and certified care workers under the scheme of Economic Partnership Agreements (EPAs) between Japan and Indonesia in 2008, as a new policy to import more foreign skilled workers into Japan. This chapter demonstrates the nation's passive attitude toward accepting foreign workers as well as the growing demand for more consistent immigration policy in terms of language. Chapter 2 discusses the validity and accountability of the current major influential assessment tool in Japan, Japanese Language Proficiency Test (JLPT). It includes a discussion of how linguistic 'proficiency' is understood in the JLPT and reveals its problems, comparing JLPT with other influential measurement tools in the world such as the American Council on the Teaching Foreign Language-Oral Proficiency Interview (ACTFL-OPI) and the Common European Framework of Reference for languages (CEFR).
\end{abstract}




\section{Acknowledgement}

First and foremost, I would like to thank my committee members for their support and understanding throughout the thesis process. My heartfelt appreciation goes to my thesis advisor, Dr. Patricia Wetzel. I could not have gotten as far as I have without your guidance, astute advice, and perceptive insight. My special thanks to Dr. Laurence Kominz and Dr. Suwako Watanabe for promoting a love of literature, and providing many opportunities for experience, growth, and support throughout my time in the United States. I cannot forget my numerous friends and colleagues who shared their invaluable thoughts, critiqued and allowed me to discuss this thesis; Misuzu Kazama, Satomi Hayashi, Mami Harano, Takako Wolf, Hiroko Katsuta, Keiko Sugiue, Greg Van Buren, Hironori Nishi, and Fumi Maekubo. I owe many thanks to the wonderful faculty and staff who encouraged me and fostered my love for teaching. Finally, I thank my family whose unfailing confidence and support saw me throughout this endeavor. Thanks for everything you have done over the years of my education. My thesis project would not have seen completion without them. 
Table of Contents

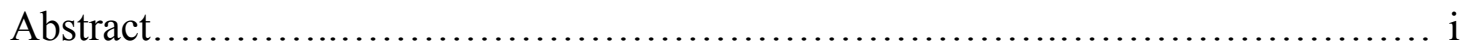

Acknowledgements....................................................... ii

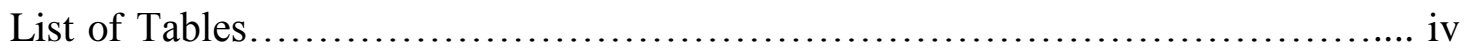

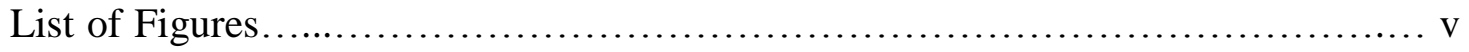

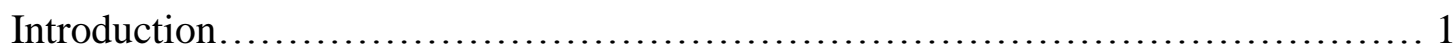

Chapter 1

Japan in an Age of Migration.............................................. 3

Chapter 2

The Current Immigration Policy: Language and Future Challenges................. 24

Conclusion......................................................... 53

References......................................................... 59

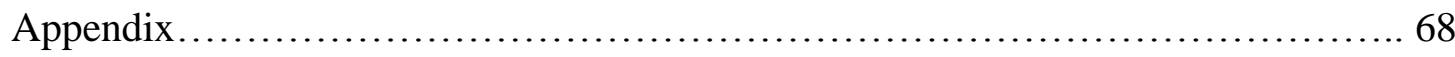




\section{List of Tables}

Table 1.2.1-1. Turn-over rate, monthly salary and working condition by

occupation......................................................... 11

Table 2.1-1. Explication of how the new JLPT compares to the former JLPT........ 25

Table 2.1-2. JLPT: linguistic competence required for each level................. 25

Table 2.2.1-1. ACTFL assessment criteria: speaking proficiency................. 42

Table 2.1.2-1. CEFR Common reference levels: self-assessment grid.............. 49 


\section{List of Figures}

Figure 1.1.1-1. Population development in Japan................................ 4

Figure 1.2.2-1. National surveys on accepting foreign workers (1)................ 13

Figure 1.2.2-2. National surveys on accepting foreign workers (2)................ 14

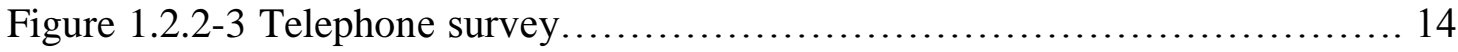

Figure 1.2.2-4. National surveys on accepting foreign workers (3) $\ldots \ldots \ldots \ldots \ldots \ldots \ldots$

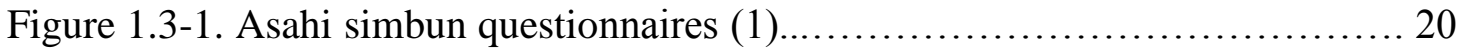

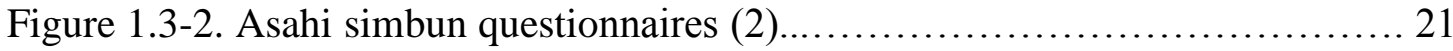

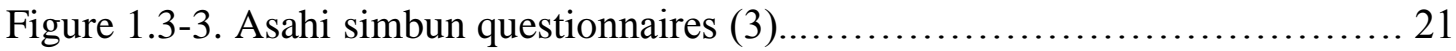

Figure 2.2.1-2. Areas of language knowledge................................ 45 
Introduction

In the context of demographic change - a rapidly aging and dwindling population-Japan is facing a particularly sensitive moment which will influence the country's future. In 2008, the country, which still views itself as a racially and culturally homogeneous country, decided to open its labor market (the health care industry) to foreigners under a series of bilateral Economic Partnership Agreements (EPAs). The country succeeded in launching a new policy to import more foreign skilled workers into Japan; however, this acceptance also gives rise to ethical questions of integrating foreign workers into the society. Japan born residents have high expectation for the Japanese language ability of those they interact with in a health care context and the language barrier and unfamiliar workplace environment pose daily challenges to foreign candidates for nursing and certified care jobs. The slow intake of foreign workers is believed to stem from concerns by hospitals and nursing care facilities about the obligations that they would take on in accepting foreign nurses and certified care workers from Indonesia, such as having to teach them Japanese, providing for their living expenses and so forth. The six months of Japanese language training for foreign candidates under the scheme of EPA, which sets a target of JLPT Pre-level 2, is not sufficient for many of the immigrants. This, in turn, gives rise to questions about the JLPT as an assessment tool for linguistic proficiency. It is difficult to measure language ability, namely what a speaker can perform and accomplish in terms of real-world task, through a multiple-choice exam. Compared to ACTFL-OPI and CEFR, the JLPT lacks credibility for measuring linguistic 
proficiency for real world purposes. This thesis concludes that an ACTFL OPI-like test is more reliable in measuring a speaker's proficiency. The identification of the kind of language proficiency needed by Japanese citizens to interact and co-operate effectively, describing them as accurately and usefully as possible, and ranking of illocutionary acts in terms of appropriateness and level, for example, is extremely complex but necessary in this era of globalization. The intentions and objections of the proficiency movement in the United States and Europe are laudable and give explicit insight for future development of assessment tools for language proficiency in Japan. 
1. Japan in an Age of Migration

\subsection{Population Projections for Japan}

\subsubsection{Population Statistics in Japan ${ }^{1}$}

Demographic transformation such as the one occurring in Japan right now has profound implications for a nation's future. The shrinking number of working-age citizens limits economic growth, cuts tax revenues, squeezes governmental budgets, and reduces financial options. Like the rest of the developed countries all over the world, Japan is facing a particularly sensitive moment which will influence traditional values and preferences, affecting priorities and transforming the nation's goals.

The National Institute of Population and Social Security Research (Kokuritsu Syakaihoshō/Jinkō Mondai Kenkyūjo), formerly the Institute of Population Problems (Jinkō Mondai Kenkyūjyo), has been projecting future population developments in Japan since $1955 .^{2}$ According to Population Statistics of Japan 2008 (2009), the population of 127.77 million as of 2005 will decrease to less than 100 million by 2046 and fall even further to below 90 million by 2055 , which means Japan will lose some $30 \%$ of its population in

\footnotetext{
${ }^{1}$ I will not provide an in-depth analysis of the general data on Japan's demographic change here, since the most important point for my argument - Japan's demographic need for labor migration and the way to integrate those foreign workers in terms of language - is the decline of Japan's workforce in particular.

${ }^{2}$ Recently, in particular, the National Institute of Population and Social Security Research has been making projections of the total population living in Japan, population distribution by prefecture, the number of households and other indexes every 5 years, in synch with the public announcement of the Population Census.
} 
the coming fifty years. If it is assumed that there are no immigration entries and exits at this point, the long-term increase and decrease of the population is determined by the levels of fertility and mortality. Since the fertility rate in Japan has been dropping for more than 30 years, ever since 1974, constantly remaining below the "population replacement level,",3 the consequence is that "Japan is entering a period of depopulation" (Kaneko et al., 2009, p.6).

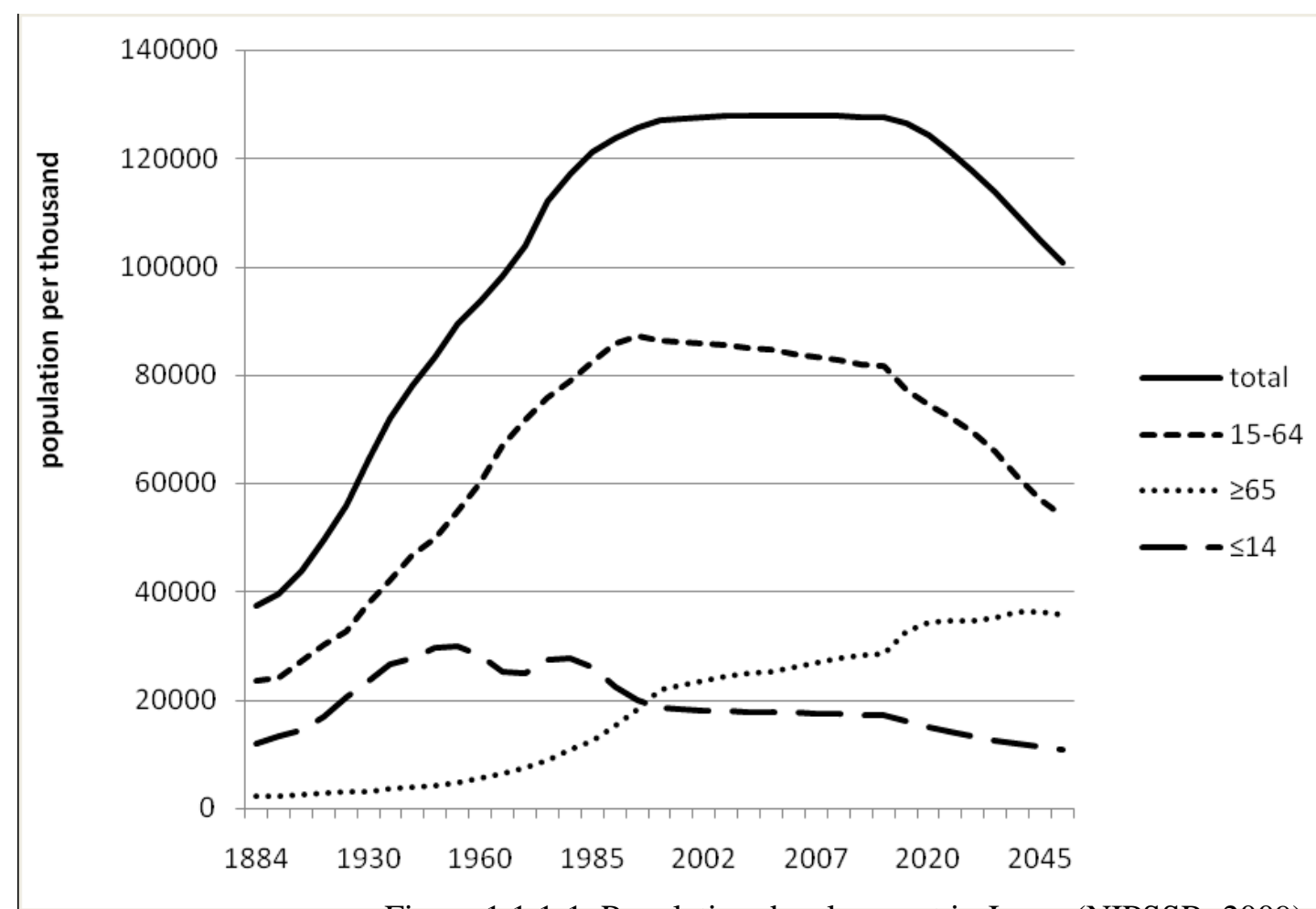

Figure 1.1.1-1. Population development in Japan (NIPSSR, 2009)

Japan faces the serious concern of an extremely low birthrate, 1.37 as of 2008 (Ministry of Health, Labour and Welfare (MHLW), 2009a), as well as rapid aging of the population. The total number of elderly people and their

\footnotetext{
3 "The level of fertility where the population neither increases nor decreases over an extended period of time under some fixed level of mortality is called the population replacement level" (Kaneko et al, 2009, p.6).
} 
percentage of the population have reached the highest levels since statistics have been recorded, and Japan will have the highest proportion of elderly to general population in the world (Kaneko et al., 2009). Although the total population has started to decline, the population size in the bracket of 65 years of age and older will, in fact, increase. The National Institute of Population and Social Security Research (2009) showed that in 2008 25.4\% of Japanese women and $19.9 \%$ of Japanese men were 65 or over. People 70 or over numbered 20.60 million, up 440,000 from a year before, and accounted for $16.1 \%$ of the total population. People 80 or over numbered 7.89 million, up 390,000 , and made up $6.2 \%$ of the total population. As of $2008,19.77$ million households, or $41.2 \%$ of the nation's total number of households, have one or more people aged 65 or older and in 4.35 million households, or $22.0 \%$ of the nation's total, an elderly person is living alone (MHLW, 2009b). Living alone can be very hard for elderly people unless they are lucky enough to have friends, relatives or professional certified care workers with whom they can freely talk or meet. The increase of solitary death among elderly persons has become recognized as a serious problem in Japan. At a time when the labor force is shrinking because of the falling birthrate and the aging population is skyrocketing, the acceptance of a foreign work force and the questions of how those foreign workers are prepared in terms of language are now moving into the spotlight. 


\subsubsection{International Worker Migration to Japan}

Compared to German and French immigration policies, which provoked a sharp backlash from foreigners, Japanese immigration control policies are more consistent-for better or for worse-in their policy of simply not taking in unskilled foreign workers. ${ }^{4}$ Also, the government had attempted to maintain homogeneity in immigration by allowing only workers of Japanese descent (nikkei) to come to Japan. In fact, from the latter half of the 1980s, the immigration of Japanese-Brazilians into low-income jobs—often described as the " $3 \mathrm{~K}$ " (—kitanai (dirty), kiken (dangerous), and kitsui (hard))-occurred in the context of Japan's demographic labor shortage and rapid economic growth. However, the number of available nikkei diaspora representatives has reached a plateau, and there are fewer nikkei laborers available now (Douglass and Roberts, 2003, p. 7). The country's impending depopulation and aging society point to a greater certainty that the global age of migration has come to stay. This demographic event decisively shifts the discourse about immigration policy in Japan. The government is seeking ways to actively import skilled foreign workers now.

On July 1, 2008, an Economic Partnership Agreement (EPA) between Japan and the Republic of Indonesia entered into force. ${ }^{5}$ This EPA is Japan's

\footnotetext{
${ }^{4}$ This paper does not directly address the status of unskilled workers in Japan.

5 The pact was finally sealed on August 20, 2007 when Japanese Prime Minister Abe Shinzo and President Susilo Bambang Yudhoyono signed a Memorandum of Understanding during Abe's three day visit to Indonesia.
} 
sixth EPA, following the Japan-Singapore, Japan-Mexico, Japan-Malaysia, Japan-Chile, and Japan-Thailand EPAs. On the face of it, the agreement aims to enhance economic cooperation between the two countries by boosting bilateral trade, facilitating Japanese investment and conducting industrial capacity-building programs (Ministry of Economy, Trade and Industry (METI), 2008). The new Japan-Indonesia EPA also has the distinction of having agreed to accept into Japan some four hundred skilled nurses and six hundred certified care workers from Indonesia over the succeeding two years. For the Japanese government, this new Japan-Indonesia EPA is important not only in strengthening the economic partnership among Asian countries, but also in determining whether and how foreign skilled workers can be imported into the country. Japan also concluded a similar EPA with the Republic of the Philippines on December 11, 2008 and planed to accept the same number of medical staff as from Indonesia over the succeeding two years.

On August 7, 2008, a total of 208 Indonesian workers (104 potential nurses and the same number of certified care workers) came for the first year of the program (MLHW, 2009c). The EPA condition for nurses is that they are licensed in Indonesia and have more than two years' experience, and certified care workers should have at least three years of higher education (because there are no licenses for certified care workers in Indonesia). With the assistance of the Japan International Cooperation of Welfare Services (JICWELS), the potential nurses contracted with 47 Japanese institutions and 
the certified care workers with 51 institutions in 34 prefectures. After undergoing six months of language training by the Association for Overseas Technical Scholarship (AOTS) or the Japan Foundation (JF), all of the Indonesian workers began to work in hospital or medical facilities in Japan. ${ }^{6}$

Japan succeeded in launching a new policy to import foreign skilled workers under the scheme of EPAs. However, these bilateral EPAs also give rise to ethical questions of integrating foreign workers into a society that views itself to be racially and culturally homogeneous and has historically enforced policies to limit the entrance of foreign workers into the country. More immigrants are coming and establishing their own lives in Japan. A change in Japan's demographic profile is inevitable. Unlike most other developed countries, the number of foreign residents in Japan is extremely low, just 2.2 million people or $1.74 \%$ of the overall population as of 2008 (Ministry of Justice (MOJ), 2009). International migration to Japan is extremely low and its impact on population change has also been small until now. However, not only is the demand for labor growing in Japan, but migrant-sending countries are also becoming dependent upon remittances from their workers abroad to sustain their economic well-being in the era of globalization (Douglass and Roberts, 2003). Japan, which has become one of the key migrant-receiving countries since the 1980 s, had a total of nearly 2.1 million registered foreign residents at the end of 2008. That number had

\footnotetext{
${ }^{6}$ The potential Indonesian certified care workers also underwent the introductory orientation for nursing care for elderly by Japan International Corporation of Welfare Services (JICWELS).
} 
increased by 700,000 (up 46.6\%) since the end of 1998 (MOJ, 2009). The International Labour Organization (ILO) (2001) concluded that these increases tie into a larger issue, which is the wide wage gap between Japan and other Asian countries and Japanese workers' unwillingness to take menial jobs.

\subsection{Issues in Accepting Foreign Workers}

\subsubsection{Nursing Shortage in Japan}

As noted earlier, Japan is facing the very concrete economic demands of an aging society. To cope with the reality of the aging society, demand for nurses and certified care workers has been increasing in proportion to the increase in the number of medical institutions. Under the scheme of EPAs, the country opened up the national labor market to foreign nurses and certified care workers for the first time in history. Although the MHLW as well as the Japan Business Federation (Nippon Keizai Dantai Rengōkai) denied that the purpose of the program was to make up for a labor shortage, with the population continuing to age, the nursing field especially for the senior care industry needs a massive injection of labor.

According to the "Survey on Actual Condition of Certified care workers in fiscal 2008" (Heisei 20nendo Kaigo Rōdō Jittai Chōsa) conducted by the Care 
Work Foundation (Kaigo Rōdō Antei Sentā, 2009), the turnover rate of certified care workers is high, hitting $21.9 \%^{7}$ in fiscal 2008; while the overall average of full-time workers ${ }^{8}$ is $14.6 \%$ (MHLW, 2009d). The average monthly salary of certified care workers was 216,500 yen (about 2,165 US dollars) which is quite low compared to the overall average (overall average is 299,100 yen (MHLW, 2009e)); When asked about their working condition, $58.3 \%$ of respondents answered (multiple answers were allowed): "despite the hard physical work (which includes night shifts and assisting people with bathing and going to the restroom), it is a low-paying job," followed by "being short of hands" (51.0\%), "social valuation of care work is low" (41.3\%). Not only financially but also socially, care work is not a glamorous job for young Japan-born residents. An estimated number of close to half a million trained Japanese certified care workers work in other professions in addition to their care work employment (Japan Nursing Association (JNA), 2008a).

As for nurses, the shortage hits rural areas hardest because nurses tend to seek jobs at large hospitals in cities where the pay is higher. Moreover, a change in the medical treatment fee system in April of 2006, which allows hospitals with a high ratio of nurses per patient to receive additional fees, precipitates the irregularity of the nurse population between regions. While the

\footnotetext{
${ }^{7}$ This number is the pure turnover rate of certified care workers who work at medical institutes where foreign potential certified care workers are supposed to work, which does not include that of home helpers who visit elderly households, $13.9 \%$.

${ }^{8} \mathrm{~A}$ full-time worker defined in this survey corresponds to any of the following. 1. A worker who is employed permanently rather than a short term. 2. A worker who is employed more than a month. 3. A temporally worker who is employed less than a month, and who worked more than 18 days.
} 
well-financed hospitals with sufficient nurses are continuing to recruit, the small and medium-sized hospitals or rural hospitals are forced to reduce their number of beds. The average monthly salary of nurses is not so bad, 322,000 yen (about 3,220 US dollars) (MHLW, 2009e), which exceeds the overall average, 299,100 yen. However, the job is also known for its hard work. One out of twenty-three nurses has a heavy workload, more than 60 hours overtime per month, which contributes to a dangerous level of death from overwork (JNA, 2009).

\begin{tabular}{|c|c|c|c|}
\hline & Turn-over rate & Monthly salary & Working Condition \\
\hline Care Workers & $21.9 \%$ & $\$ 2,165$ & $\begin{array}{l}\text { - hard physical work } \\
\text { - being short of hands } \\
\text { - social valuation is low }\end{array}$ \\
\hline Nurses & $11.9 \%$ & $\$ 3,220$ & $\begin{array}{l}\text { - rural imbalance in numbers } \\
\text { - (rural area) a lot of overtime work }\end{array}$ \\
\hline Overall Average & $14.6 \%$ & $\$ 2,991$ & \\
\hline
\end{tabular}

Table 1.2.1-1. Turn-over rate, monthly salary and working condition by occupation

The JNA stands firm on its principle that health-care migration is a matter of solving the trade imbalance between two nations by adding professionals as the subject of export and import, which is only allowed under the scheme of EPAs. However, it is unrealistic to rely on only Japanese-born residual nurses, including qualified nurses who are not active on the front lines. ${ }^{9}$ Current

\footnotetext{
${ }^{9}$ In late 2002, the MHLW estimated that there are some 550,000 Japan-born residual nurses who have left their jobs or who are on leave (31.11\% of overall license holders). And in the follow-up survey which was conducted by Miyazaki and Nakata (2008) in late 2006, it was revealed that both the number and percentage of nurses who have left their jobs or who are on leave increased by 650,000 (34.48\% of overall license holders).
} 
projections indicate that four out of ten Japanese will be over the age of 60 by the middle of this century, and there may not be enough people of working age to support them. Japan and other developed countries now face an acute shortage of nurses and certified care workers. As most of these countries have been endeavoring to accept qualified medical workers from abroad, Japan has finally opened its labor market to foreign workers under the scheme of EPAs.

\subsubsection{Attitude and Argument Over Accepting Foreign Nurses and Certified}

\section{Care Workers}

According to the "National survey on accepting foreign workers"

(Gaikokujin rōdōsya ukeire ni kansuru yoronchōsa) conducted by the Cabinet Office in 2004, when asked about accepting foreign workers as a partial solution to the labor shortage, $15.3 \%$ of citizens answered: "The acceptance of foreign workers should be considered positively because the indigenous labor force is limited even if the use of female and elderly workers is promoted successfully"; $45.0 \%$ answered "The use of more female and elderly workers, improvement of working environment, technological innovation and investments in information technology etc. for higher labor productivity should be considered first. If the country is still short of workforce, foreign workers should be accepted"; $29.1 \%$ answered "The labor shortage should be solved by using more female and elderly workers, improving working environment, innovating new technology, and investing in information technology etc. for higher labor productivity, and foreign workers should not be accepted without 
thorough consideration.” Most Japanese citizens are receptive to accepting foreign workers; however, they maintain a passive attitude. The deteriorating employment of domestic workers as well as national security often come up as issues when discussing international labor migration. However, international labor migration is a global trend, and it does not happen if a migrant-receiving country does not have demand. (See figure 1.2.2-1.)

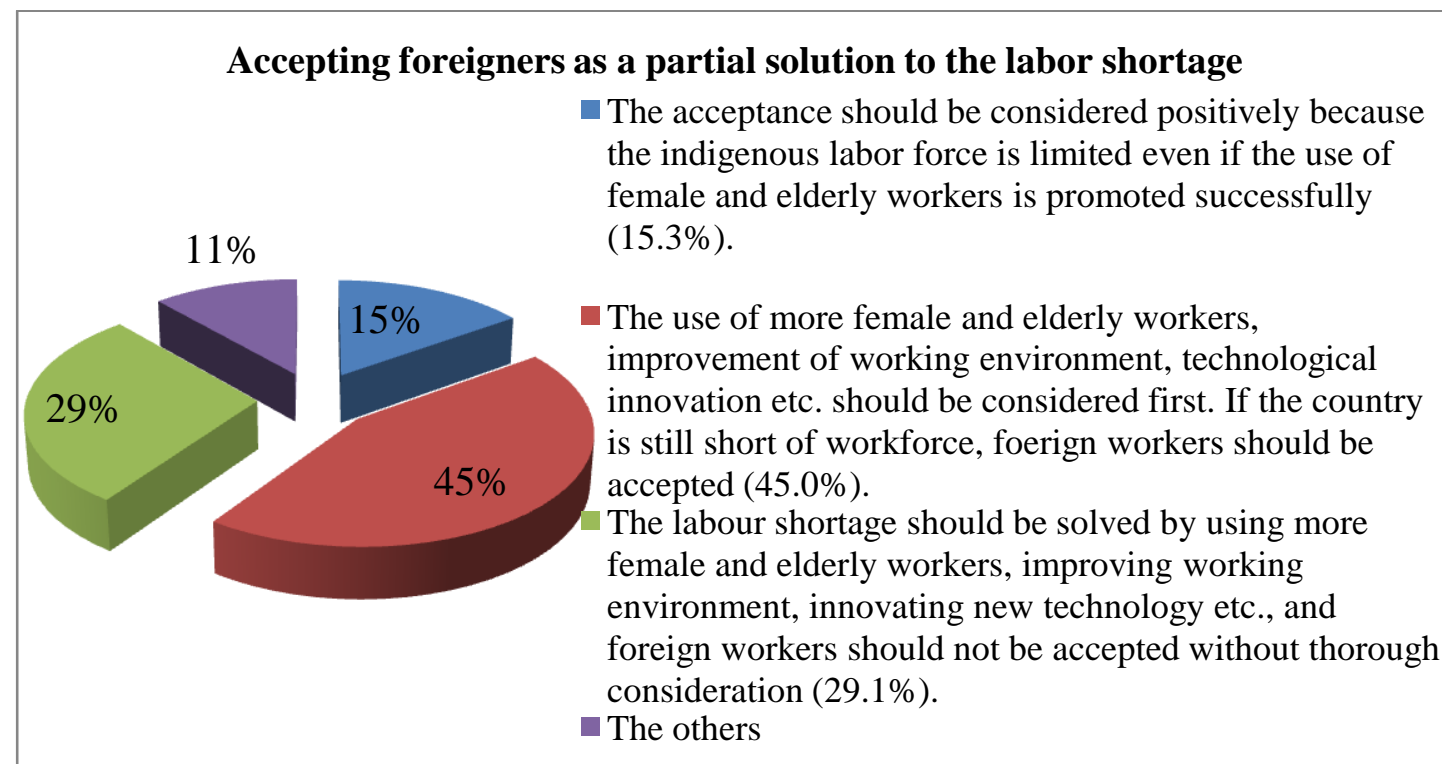

Figure 1.2.2-1. National surveys on accepting foreign workers (1) (Cabinet Office, 2004).

When asked about acceptance of job fields that Japan-born residents are unwilling to take on, $32.6 \%$ of Japanese respondents answered "It is bad to think that foreign workers should take on the jobs that Japan-born residents are unwilling to take"; $31.1 \%$ answered "If foreign workers are willing to take on those job, it is extremely favorable"; $28.4 \%$ answered "It is not good, but inevitable" (Cabinet Office, 2004). 


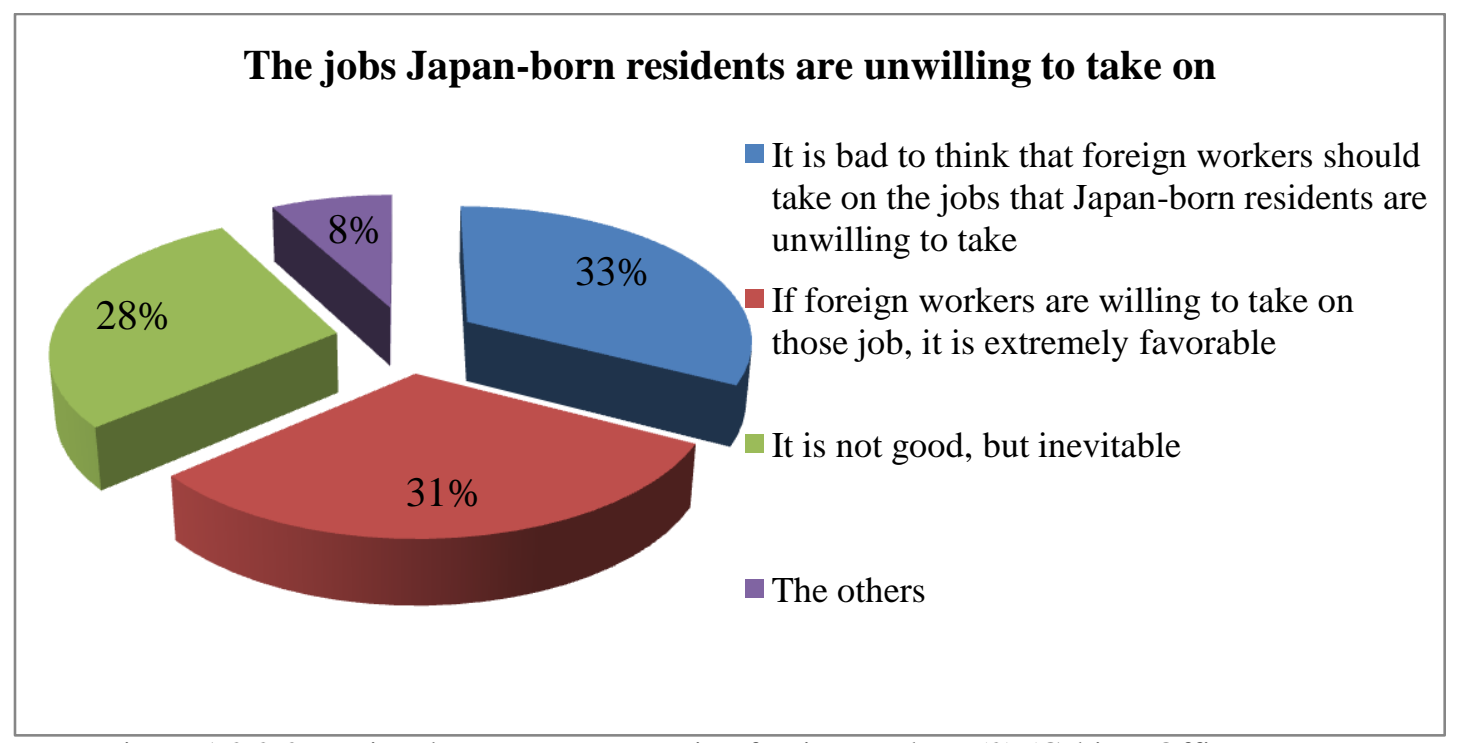

Figure 1.2.2-2. National surveys on accepting foreign workers (2) (Cabinet Office,

Some ethical questions persist, but Japan has already appeared on the international stage as one of the migrant-receiving countries. According to a telephone survey by the Sankei Shimbun in 2009 on the acceptance of foreign nurses and certified care workers, $58 \%$ of respondents agreed with accepting foreign medical staff into the medical field (42\% disagreed). When asked if they have reservations about receiving medical treatment from foreigners, $56 \%$ answered "Yes" (44\% answered "No").

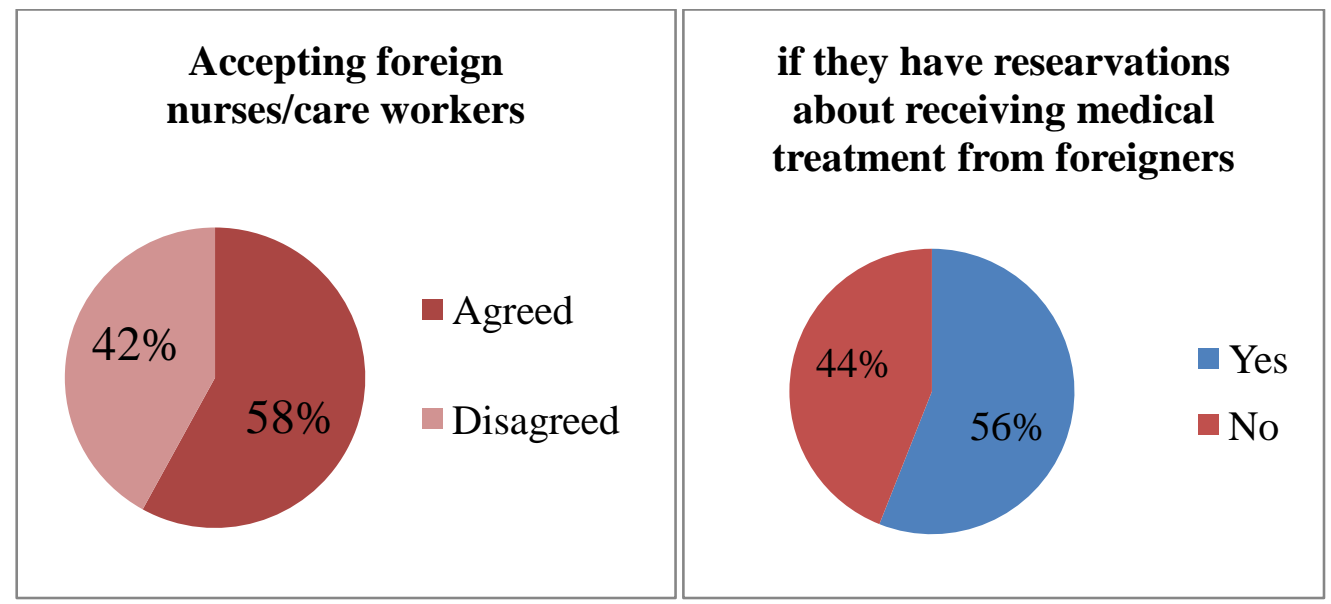

Figure 1.2.2-3. Telephone survey (Sankei Shimbun, 2009). 
When asked about the most important quality of foreign workers, $35.2 \%$ of Japanese respondents answered "Japanese-language ability"; $32.7 \%$ answered "Japanese cultural understanding"; 19.7\% answered "professional skill, knowledge and expertise" (Cabinet Office, 2004). Japanese residents have high expectations regarding the language ability of foreign workers.

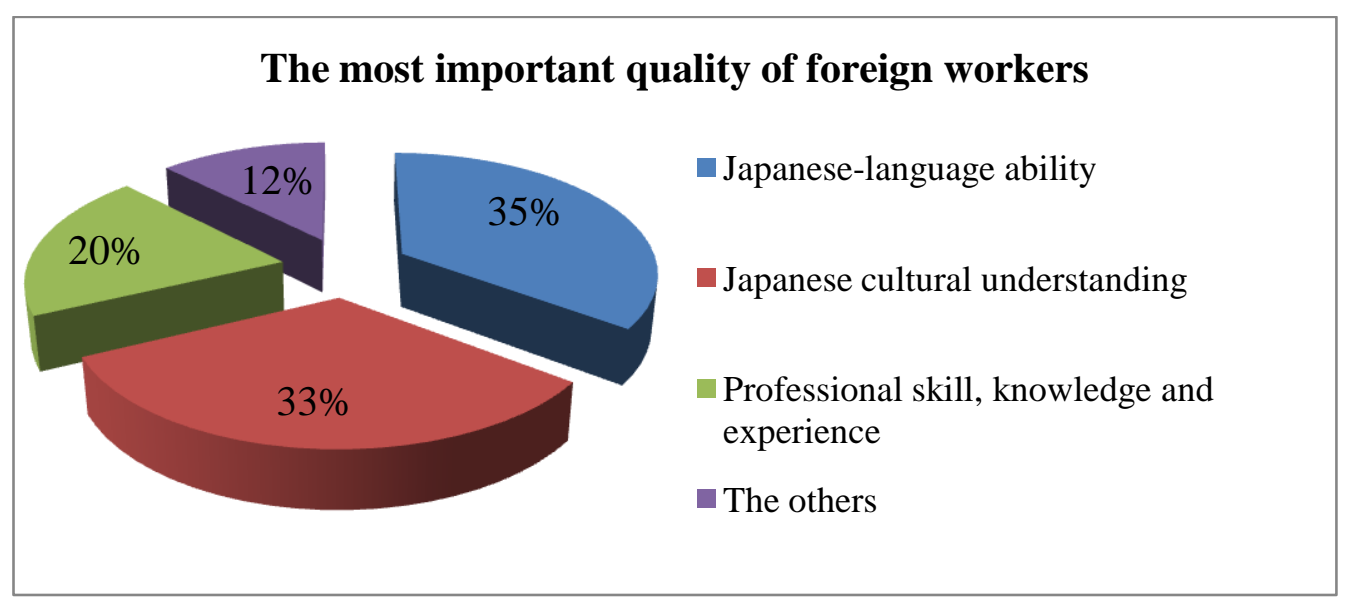

Figure 1.2.2-4. National surveys on accepting foreign workers (3) (Cabinet Office, 2004).

One of the most influential opponents of accepting foreign medical staff is the JNA (2008b), which represents most nurses in the country. The JNA proposes the following four conditions for foreign nurses to work in Japan: (1) To pass Registered Nurse National Board Examination to qualify for Japanese nursing licensure; (2) To obtain Japanese language proficiency to provide safe nursing care; (3) To be employed in Japan under conditions equal to or better than those for Japanese nurses; and (4) To apply no mutual recognition to nursing licenses from abroad. Passing the national exam (\#1), which is written in Japanese and includes difficult medical terminology, requires considerable Japanese-language ability. Once medical staff under the EPAs start to work, 
they are required to pass national exams, within three years for nurses and four years for certified care workers, ${ }^{10}$ and if they fail, they have to return home (MHLW, 2009c). The pass rate for the national exams is $90.2 \%$ for nurses and $52.0 \%$ for certified care workers (MHLW, 2009f). It goes without saying that Japanese-language ability is critical to passing the national exams and remaining in Japan.

The slow intake of foreign workers is believed to stem from concerns by hospitals and nursing care facilities about the obligations that they take on in accepting foreign nurses and certified care workers from Indonesia and the Philippines—-such as having to teach them Japanese, their living expenses and so forth. ${ }^{11}$ According to "The framework for accepting Indonesian nurses and certified care workers in fiscal 2009" (Heisei 21nendo Indoneshiajin Kangosi/ Kaigohukushishi Ukeire no Wakugumi) by the JICWELS, those medical facilities have to pay more than 565,000 yen (about 5,650 US dollar) to accept one Indonesian worker-application fee 31,500 yen; mediation fee 138,000 yen per person; commission for the National Board 15,000 yen per person; service charge (counseling for Indonesian workers, hospitals and institutions) 21,000 yen per person per year; Japanese language training, travel expense and living expense during training about 360,000 yen per person. It is estimated

\footnotetext{
${ }^{10}$ The Indonesian candidates for nurses have the opportunity to take the annual exams three times within three years of their arrival. However, candidates for care workers can only take the test once, because the exam requires candidates to have three years of work experience as care workers. ${ }^{11}$ Hitherto, 208 Indonesian medical workers arrived in August of 2008, 361 Indonesian workers in November of 2009 (Japan was supposed to accept 1000 medical workers over the succeeding 2 years.) and 280 Filipino workers in May of 2009 (Japan agreed to accept the same number as Indonesia).
} 
that potential foreign nurses and certified care workers will earn less than what licensed Japanese nurses and certified care workers make because they will work as assistants in those facilities while they study for tests to qualify as fulltime nurses and certified care workers. Thus it is a huge investment for the small and medium-sized hospitals or rural hospitals. The related ministries and agencies such as MHLW, MOFA, and Agency for Cultural Affairs, and institutions such as the AOTS lack the solidarity required for dealing with the issues.

The acceptance of foreign workers is viewed as international cooperation for the following reasons: international human movement from a laborabundant country to a labor demanding country can enhance welfare in the world, the money sent by foreign workers to their home country can redress the gap between the developed countries and developing countries, the acceptance of foreign workers in Japanese companies can promote transfer of technology. Although the concept of international cooperation is a part of the obligation of developed countries exploiting today's third world, the author believes the acceptance of foreign workers should not be discussed sentimentally. If the country decides to accept foreign workers, their status and security of work and living should be protected by the government just as the country does for its native-born residents. Japanese language teaching plays an important role in integrating foreign workers as new long-term residents in Japan. 


\subsection{Japanese Language Teaching for Foreign Candidates for Nursing and Care}

Jobs

The first group of 208 Indonesian candidates for nurses and certified care workers under the EPA underwent Japanese language training and started work right after the language training. ${ }^{12}$ It still remains to be seen whether those foreign workers have met the required level of Japanese language proficiency for their job performance. Even though the host residents, Japan-born citizens, are most concerned about the Japanese language ability of foreign workers, there was no entry requirement for Japanese language proficiency in this program. 104 potential nurses and 101 certified care workers underwent the Japanese language training, and three of the certified care workers were exempt from the training because their Japanese language ability corresponded to approximately Japanese Language Proficiency Test (JLPT) Level 2.

For six months of Japanese language training for potential nurses and certified care workers, the AOTS made a new 675 hour curriculum, which sets a target of JLPT Pre-level 2, focusing on conversation between co-workers, managers and patients, and beginning medical terminology (AOTS, 2009). ${ }^{13}$ After undergoing six months of Japanese language training, have Indonesian medical staff acquired sufficient Japanese language ability to perform the job? The acceptance of foreign

\footnotetext{
${ }^{12}$ The potential Indonesian care workers also underwent the introductory orientation for nursing care for elderly by Japan International Corporation of Welfare Services (JICWELS).

${ }^{13}$ The author attempted to get details on the current curriculum used in teaching prospective health care workers but had little success. An email inquiry was rebuffed with the response, 'this is a confidential curriculum which was devoted to health care workers under the scheme of EPA. For more information, please refer to the press release.' It is therefore not clear whether the curriculum is geared toward the tests and examinations that health care workers will have to pass.
} 
medical staff under the EPA has received nationwide media attention. On March 18, 2009, the Japan Times reported on two Indonesian nurses and two care workers on the job as well as two of the receiving hospitals and nursing facilities. According to the article, although the two potential nurses, Mohamad Yusup, 27, and Erli Ridwan, 35, had finished the six months of Japanese language training and started working at Kawakita General Hospital in Tokyo, the language barrier and unfamiliar workplace environment posed daily challenges. Both of them started studying Japanese after arriving in the country and Yusup always carried a dictionary, saying "I learn new Japanese conversational terms every day." After undergoing the language training, reading remains a challenge. Japanese staff in Kawakita General Hospital attach furigana readings next to the kanji and show the pictures of medical instruments to help foreign workers' language learning and to help them cope. Tomoyo Mizumachi, a nurse in charge of mentoring the two, expressed her anxiety about teaching them "accurate" Japanese language and the philosophy underlying the Japanese ways of nursing care. Danta, 28 (who does not have a family name) and Nurma Eksita, 23 who started to work as candidates for care workers at Shin Tsurumi Home, a nursing facility in Yokohama, also found it initially difficult to assist the elderly properly because family members usually wash patients and change their diapers in Indonesia but this is expected part of care in Japan. Also Japanese patients are relatively older than their Indonesian counterparts. Emiko Nakashima, a senior official at Shin Tsurumi Home, 
acknowledged that daily conversation in Japanese was still a bit beyond the two Indonesians.

From the end of September to the middle of October of 2009, almost eight months after Indonesian workers started working, the Asahi Shimbun distributed a questionnaire targeting the 47 hospitals and 53 nursing facilities where Indonesian medical staff under EPA have worked. 86 medical institutions, excluding 14 refusals to respond as a matter of institution policy, responded to the questionnaire and Asahi Shimbun unveiled the result on November 2, 2009. When asked about the Japanese language ability of Indonesian workers, 56\% answered "dissatisfied" or "somewhat (yaya) dissatisfied." $45 \%$ of them answered "The six months of Japanese language training was insufficient."

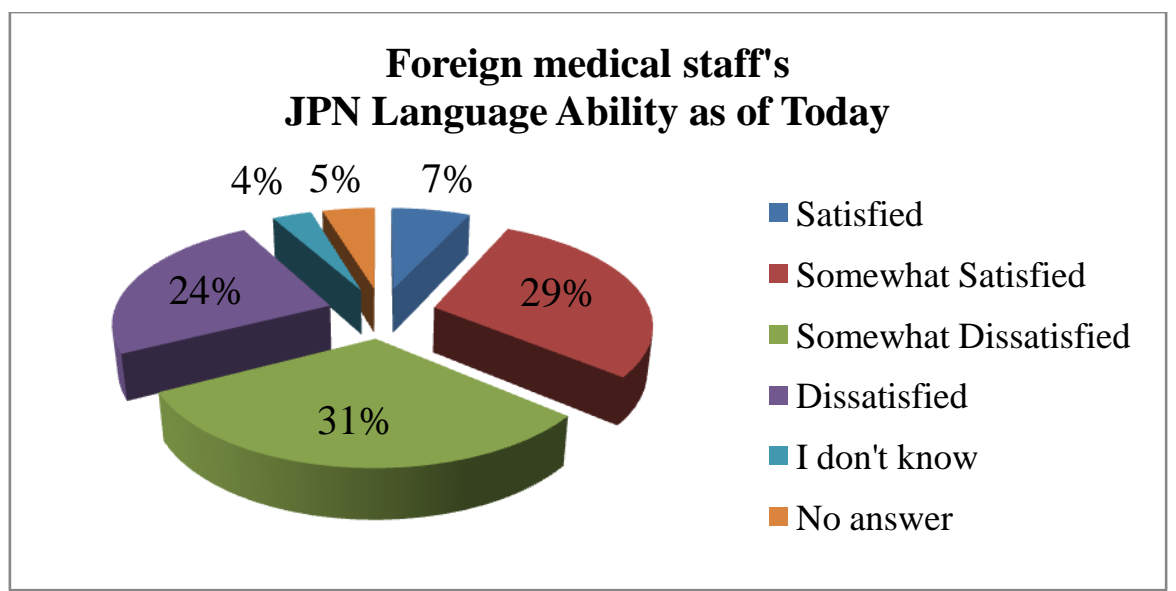

Figure 1.3-1. Asahi Shimbun questionnaires (1) (2009)

Moreover, when asked about the possibility of passing the national board exam, $38 \%$ answered "I do not think Indonesian workers can pass the national board examination," while 17\% answered "I think Indonesian workers can pass the national board examination." 


\section{The foreign medical staff's Possibility of Passing National Board Exam}

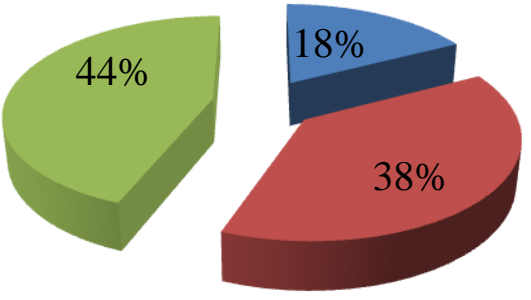

$$
\begin{aligned}
& \text { I think they will pass } \\
& \text { I do not think they will } \\
& \text { pass } \\
& \text { I don't know }
\end{aligned}
$$

Figure 1.3-2 Asahi Shimbun questionnaires (2) (2009)

More than 70\% answered "Foreign candidates should deserve some consideration," such as providing furigana reading for kanji and translation of their own language; on the other hand, 15\% (13 medical institutions, including 9 hospitals), answered "No particular consideration should be provided" due to fears of medical accidents and unfairness between Japan-born candidates and foreigners.

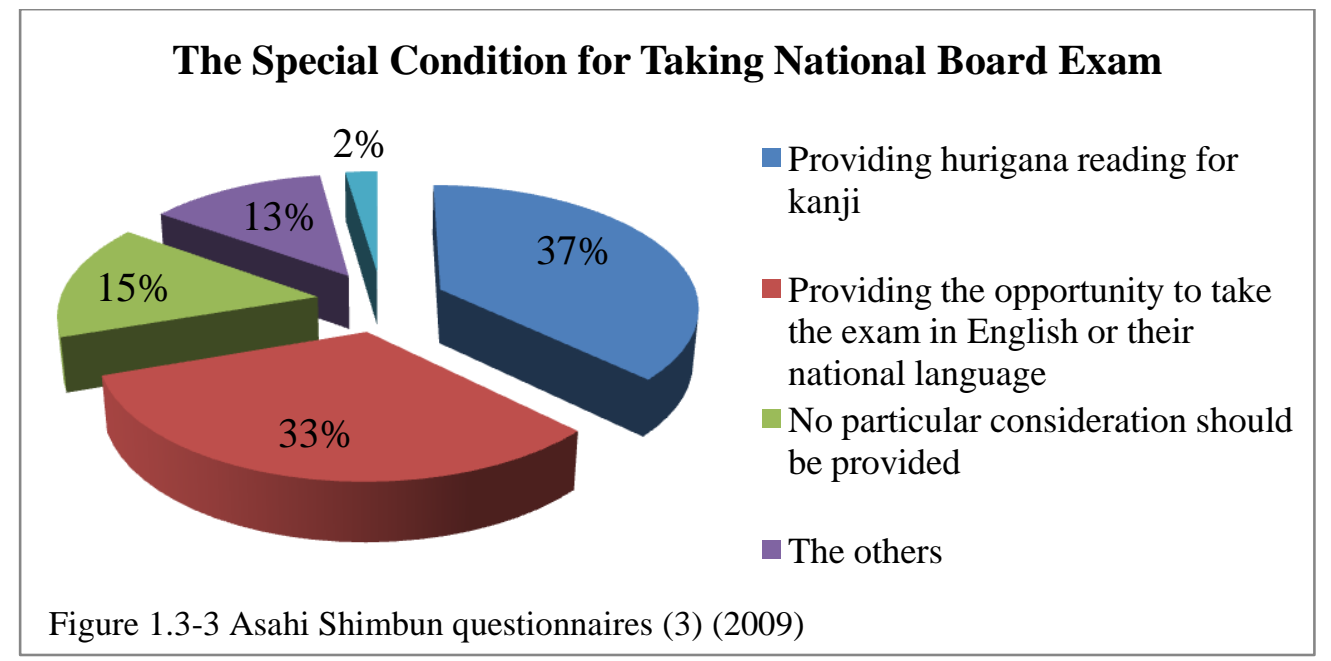

Since August 2008, only two of the 570 foreigners who have managed to pass Japan's rigorous national examinations to become certified nurses have been 
Indonesians ${ }^{14}$ (MHLW, 2010). However, 251 others from the two nations failed, apparently due to language troubles since all of them are licensed nurses who have worked more than 2 years in their home countries-while about nine out of 10 Japanese candidates passed the same exam.

On November 21, 2009, Katsuya Okada, the minister for foreign affairs of Japan, commented that the Ministry of Foreign Affairs of Japan (MOFA) is reviewing the national board examination for nurses and care workers for foreign candidates under the EPA in view of the language barrier (Nakagawa, 2009). In response, there also have been some negative comments regarding the review of the national board examination from the MHLW as well as the Japan Nursing Association and the Japan Association of Certified Care Workers.

Not all Japan-born residents hail worker migration, but most of them show an understanding of worker migration in an era of globalization. The acceptance of foreign medical workers under the scheme of EPAs delivers a certain result and is likely to accelerate the labor migration in the future. This author believes that immigration policy should be discussed rationally, not emotionally or in terms of special interests. In order to survive in the Japanese speaking community, language ability is critical and the Japanese government needs to better address the language ability of foreign medical staff who work in hospitals and medical institutes in Japan. Instead of setting up ad hoc arrangements, the Japanese government should

\footnotetext{
14 Two Indonesian nurses and one from the Philippines overcame language barriers and passed the test after coming to Japan in 2008 and 2009, the HLWM said.
} 
sort out the framework for accepting foreigners in terms of language. Affirmative action elsewhere has provoked reverse discrimination and escalated the confrontation. Foreign workers will not be treated equitably if they are accepted under particular consideration for "foreigners". 
2. The Current Immigration Policy: Language and Future Challenges

2.1. Major influential assessment tool in Japan: JLPT

In 2008, three certified care workers from Indonesia demonstrated Japanese language ability at the Japanese Language Proficiency Test (JLPT) Level Two exempting them from Japanese language training. Since that time, the JLPT has been widely used as a measurement to evaluate and certify the Japanese language ability of non-native Japanese speakers for employment screening in Japan. The JLPT is a standardized criterion-referenced test to evaluate and certify the Japanese language proficiency of non-native speakers: it has been offered by the Japan Foundation (JF) and Japan Educational Exchanges and Services (JEES) since 1984. In 2009, there were as many as 770,000 examinees from all over the world, which made the JLPT the largest-scale Japanese-language test in the world (JF and JEES, 2010).

In 2010, JF and JEES introduced a revised version of the test, ostensibly emphasizing both practical Japanese communicative competence and knowledge of the Japanese language. Also, the new test increased the number of test levels from four to five, with level N5 being the most basic and level N1 the most advanced. The corresponding levels of the new test to that of the current test are explained as follows: 


\begin{tabular}{|c|c|}
\hline $\mathbf{N} 1$ & $\begin{array}{l}\text { Approximately the same level as the current Level } 1 \text { test, but } \\
\text { designed to measure slightly more advanced abilities. }\end{array}$ \\
\hline $\mathbf{N} 2$ & Approximately the same level as the current Level 2 test. \\
\hline $\mathbf{N 3}$ & $\begin{array}{l}\text { Positioned at a level bridging the current Level } 2 \text { and Level } 3 \\
\text { tests.(Newly established) }\end{array}$ \\
\hline N4 & Approximately the same level as the current Level 3 test. \\
\hline $\mathbf{N 5}$ & Approximately the same level as the current Level 4 test. \\
\hline
\end{tabular}

Table 2.1-1. Explication of how the new JLPT compares to the former JLPT (JF and JEES, 2010).

According to the JF and JEES (2010), those who pass at the N2 level in the new test, which corresponds to the same level in the old test, have demonstrated the ability "to understand Japanese used in everyday situations (nichijōteki na bamen) and in a variety of circumstances to a certain degree." Also, their linguistic competence is described in terms of two language activities-reading and listening (see table 2.1-2, retrieved from the JLPT official web site).

\section{Level A summary of linguistic competence required for each level \\ The ability to understand Japanese used in a variety of circumstances. $<<$ Reading >> \\ - One is able to read writings with logical complexity and/or abstract writings on a variety of topics, such as newspaper editorials and critiques, and comprehend both their structures and contents. \\ - One is also able to read written materials with profound contents on various topics and follow their narratives as well as understand the N1 intent of the writers comprehensively. $<<$ Listening $>>$ \\ - One is able to comprehend orally presented materials such as coherent conversations, news reports, and lectures, spoken at natural speed in a broad variety of settings, and is able to follow their ideas and comprehend their contents comprehensively. One is also able to understand the details of the presented materials such as the relationships among the}




\begin{tabular}{|c|c|}
\hline & $\begin{array}{l}\text { people involved the logical structures, and the essential } \\
\text { points. }\end{array}$ \\
\hline N2 & $\begin{array}{l}\text { The ability to understand Japanese used in everyday situations, and in a } \\
\text { variety of circumstances to a certain degree. } \\
\text { < } \\
\text { - Reading > } \\
\text { One is able to read materials written clearly on a variety of } \\
\text { topics, such as articles and commentaries in newspapers and } \\
\text { magazines as well as simple critiques, and comprehend their } \\
\text { contents. } \\
\text { - One is also able to read written materials on general topics } \\
\text { and follow their narratives as well as understand the intent of } \\
\text { the writers. } \\
\text { < } \\
\text { One is able to comprehend orally presented materials such as coherent } \\
\text { conversations and news reports, spoken at nearly natural speed in } \\
\text { everyday situations as well as in a variety of settings, and is able to } \\
\text { follow their ideas and comprehend their contents. One is also able to } \\
\text { understand the relationships among the people involved and the } \\
\text { essential points of the presented materials. }\end{array}$ \\
\hline N3 & $\begin{array}{l}\text { The ability to understand Japanese used in everyday situations to a certain } \\
\text { degree. } \\
\text { <<Reading > } \\
\text { • One is able to read and understand written materials with specific } \\
\text { contents concerning everyday topics. } \\
\text { - One is also able to grasp summary information such as newspaper } \\
\text { headlines. } \\
\text { - In addition, one is also able to read slightly difficult writings } \\
\text { encountered in everyday situations and understand the main points of } \\
\text { the content if some alternative phrases are available to aid one's } \\
\text { understanding. } \\
\text { - One is able to listen and comprehend coherent conversations in } \\
\text { everyday situations, spoken at near-natural speed, and is generally } \\
\text { able to follow their contents as well as grasp the relationships among } \\
\text { the people involved. }\end{array}$ \\
\hline N4 & $\begin{array}{l}\text { The ability to understand basic Japanese. } \\
\text { <<Reading >> } \\
\qquad \quad \text { One is able to read and understand passages on familiar daily topics } \\
\text { written in basic vocabulary and kanji. } \\
\text { <<Listening }>>\end{array}$ \\
\hline
\end{tabular}




\begin{tabular}{|l|l|}
\hline - & $\begin{array}{l}\text { One is able to listen and comprehend conversations encountered in } \\
\text { daily life and generally follow their contents, provided that they are } \\
\text { spoken slowly. }\end{array}$ \\
\hline $\mathbf{N 5}$ & $\begin{array}{l}\text { The ability to understand some basic Japanese. } \\
<<\text { Reading }>>\end{array}$ \\
$-\quad \begin{array}{l}\text { One is able to read and understand typical expressions and sentences } \\
\text { written in hiragana, katakana, and basic kanji. }\end{array}$ \\
- $\begin{array}{l}\text { One is able to listen and comprehend conversations about topics } \\
\text { regularly encountered in daily life and classroom situations, and is } \\
\text { able to pick up necessary information from short conversations spoken } \\
\text { slowly. }\end{array}$
\end{tabular}

Table 2.1-2. JLPT: linguistic competence required for each level (JF and JEES, 2010)

The new JLPT is a multiple-choice exam which is made up of three sections: language knowledge, reading and listening. The language knowledge section includes test items such as kanji reading, orthography, word formation, contextually-defined expressions, paraphrases, usage, sentential grammar (selecting grammar form and grammar composition) and text grammar. All written and spoken instructions are given in Japanese to make the test accessible to test takers who come from a variety of cultural and linguistic backgrounds (Nara and Noda, 2003). All options are presented in Japanese script, except in the listening comprehension section, where illustrations are used. The following are sample questions from the language knowledge section on orthography and vocabulary for JLPT N2 level (retrieved from the JLPT official web site). 
Question 1. Question on words written in kanji.

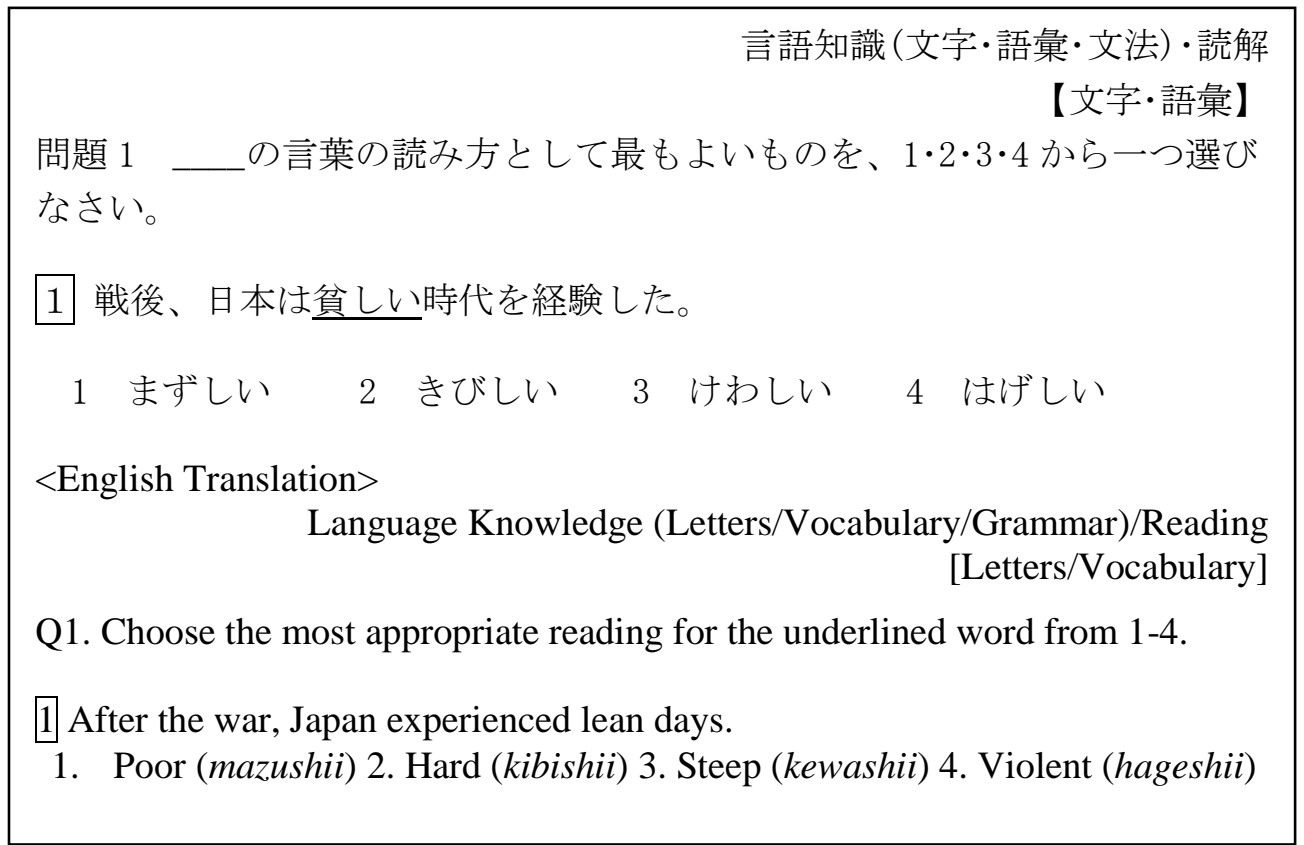

Question 2. Question on words written in hiragana.

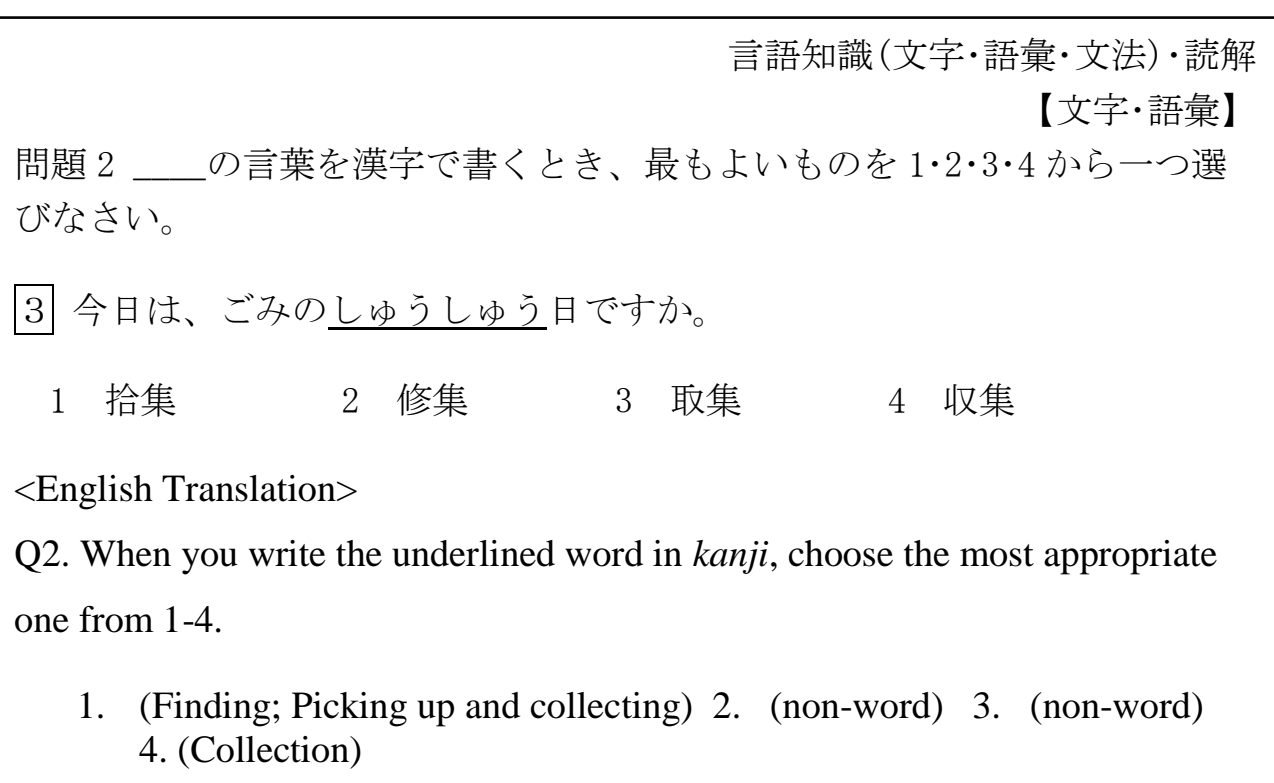


Question. 3 Question on derivative and compound words

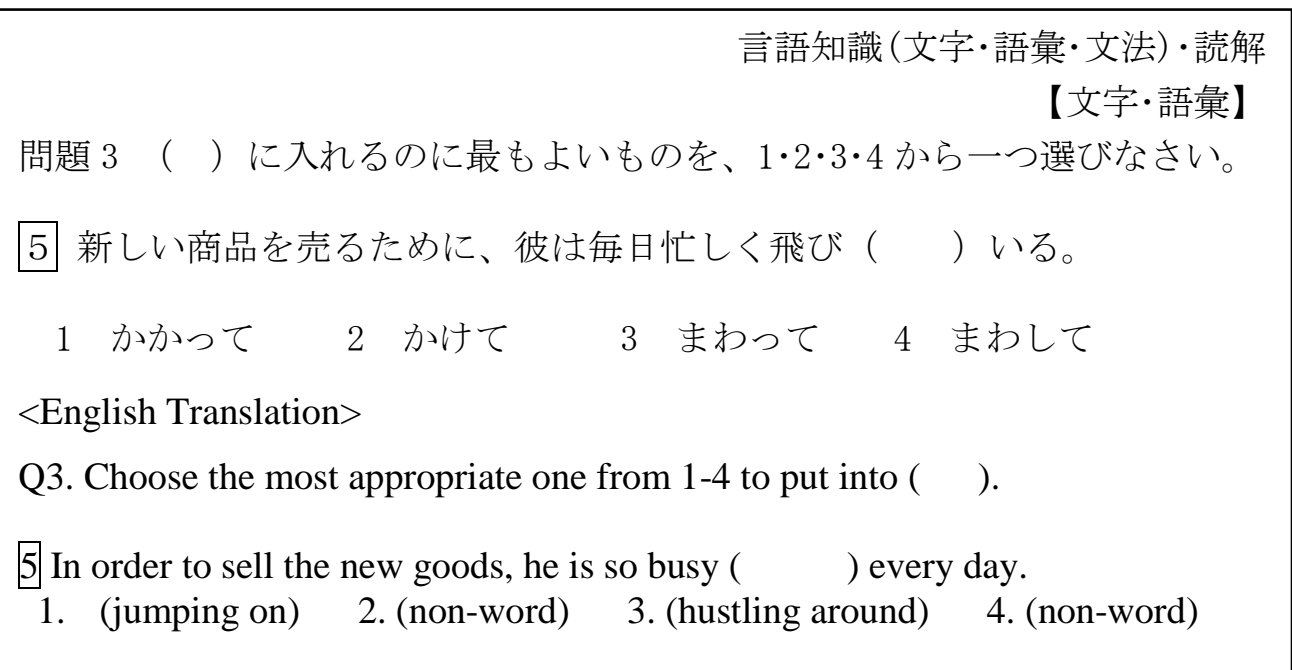

Question 4. Question on words whose meanings are defined by context.

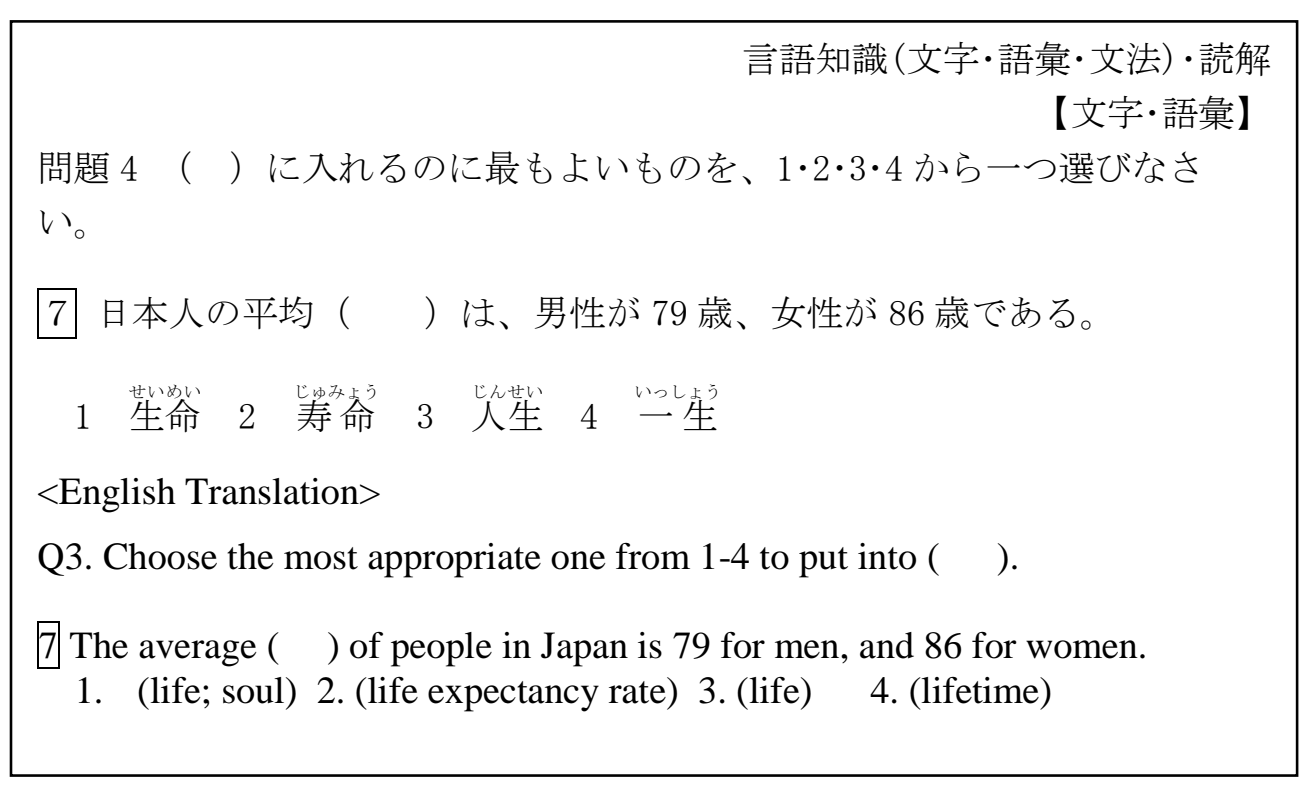


Question 5. Question on words and expressions with similar meaning.

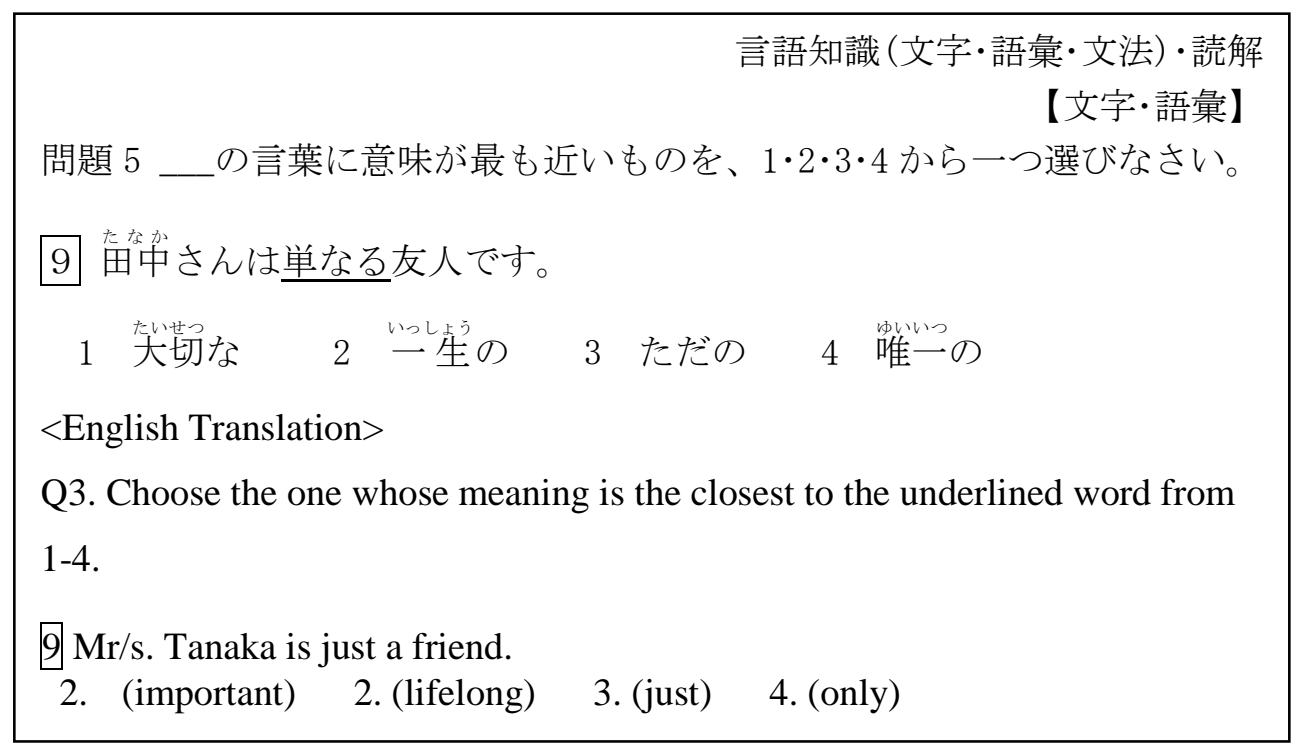

Question 6. Question on words in sentences.

\section{言語知識 $($ 文字・語彙・文法 $) \cdot$ 読解 \\ 【文字・語彙】}

問題 6 次の言葉の使い方として最もよいものを、1・2・3・4 から一つ選びなさい。

11 余計

1 一人暮らしだと野菜がすぐ余計になってしまう。

2 話が複雑になるから、余計なことは言わないで。

3 余計があったら、ひとつ貸してくれませんか。

4 このごろ仕事が忙しくて、遊びに行く余計がありません。

$<$ English Translation>

Q3. Choose the most appropriate usage for the following word from 1-4.

11 (unnecessary)

1. When living by myself, [I] immediately end up having (unnecessary) vegetable.

2. That makes things complicated. Don't say something (unnecessary).

3. If you have (unnecessary), would you lend it to me?

4. These days, $[\mathrm{I}]$ am too busy and have no (unnecessary [time]) to go hang out. 


\section{Section: Critique}

Again, according to the description provided for the JLPT N2 level, which is established as the minimum language ability required for foreign medical staff, one should be able to read newspaper articles or understand general topics and follow narratives as well as comprehend orally presented material in everyday situations (nichijōteki na bamen). For the JLPT N2 level exam furigana are provided for some kanji, such as 生命(life; soul), 寿 命 (life expectancy rate), 人生(life), 一生(lifetime), 大切(important), 唯一(only), 田中(family name) (see Q.4 and Q.5). However the criteria for deciding which characters get furigana are not clear. These kanji are jōyo kanji (literally regularly used kanji as defined by the Agency of Cultural Affairs, Ministry of Education) which means that they fall within what Japan considers to be "basic literacy." "15 Once foreign medical staff start working in hospitals or medical institutes, it is assumed that the ability to read and write a nurse/care giver's note will be required. In addition to the jōyō kanji, comprehending some medical terminology even in kanji on someone's note, is part of the "expectation." It is assumed that if the test taker is not able to read jōyo kanji and cannot choose the right one without hurigana, it is highly doubtful if he/she learned and obtained enough language ability for their job. However, this author maintains that this is not a reasonable assumption. In order to evaluate an examinee's language ability (what s/he can do in term of language on the job) a

\footnotetext{
${ }^{15}$ The current list of $j \overline{o y} \bar{o}$ kanji issued on June 7, 2010 includes 2,136 characters. The 2,136 characters in the jōyo kanji consist of kanji taught in primary school and secondary school.
} 
test needs to be developed that is based on a more accurate corpus for vocabulary and kanji, assuming control of the vocabulary that the non-native speaker will be required to use in Japan. According to the National Language Research Institute (1963), among the most frequently used kanji, one hundred account for approximately $40 \%$ of all kanji found in Japanese magazines, two hundred for $50 \%, 500$ for $75 \%$, and one thousand for $90 \%$ (cited in Hatasa, 2002, P.349). Linguistic proficiency has to be determined by what language speakers can do for real world purposes rather that what or how much they know.

Regarding the content of the exam, in order to measure the examinee's linguistic capacity, the content ranges from history (Q.1), to trash day (Q.2), to the life expectancy rate of Japanese people (Q. 4) to a personal description (Q.3\&5). According to the linguistic competence required for JLPT N2 level, candidates should be able to understand Japanese used in everyday situation (nichijōteki na bamen), and in a variety of circumstances "to a certain degree" (aru teido). The question here is what kind of situation and circumstances foreign nurses and care givers will be most likely to face in their working places and their daily life. If the foreign medical staff cannot have a chat with their patients about their interests and ask about their health/mental condition of the day, or discuss and converse about the patient's health condition and exchange updated information, their language ability cannot to be said to be sufficient for their job.

Even though Yokoyama, Kida and Kubota (2004) raise the question of the validity of JLPT as a measurement of all 4 skills (speaking, listening, reading and 
writing), it does not yet have any speaking and writing section. There is anecdotal evidence to demonstrate the lack of speaking ability of foreign nurses. Two Indonesian candidates for nurses who have worked in Sanjō, Nigata prefecture since 2008 and passed the national board exam in 2010 attended a press conference. (See appendix for entire news transcript.)

Interview transcript A: Female Indonesian nurse (26)

1.びょういんのみなさま

2.えつと あ一

3. いろいろなサポートから みなさんのおかげで わたしたちが

4. えと

5.しけんに ごかくしたら ほんとうに かんしゃしてます

6. はい

7.どもありがとございました

English Translation

1. Everyone in the hospital

2. Uh...er

3. From various supports thanks to your help We

4. Uh

5. If we could pass the exam [I] really appreciate

6. Yes

7. Thank you very much.

NHK, Nippon Hōsō Kyōkai, which broadcast their interview, also provided subtitles for one woman's speech.

$$
\begin{aligned}
& \text { 病院の皆様 いろんなサポートのおかげで } \\
& \text { 私たちは試験に合格できた } \\
& \text { 本当に感謝しています } \\
& \text { どうもありがとうございました }
\end{aligned}
$$


$<$ English Translation>

Everyone in the hospital Thanks to a various support

We could have passed the exam

I really appreciate it

Thank you very much

Although she had a foreign accent and intonation, most words were comprehensible. In line 2 and 4, she used hesitation noises such as eeto (えつと), aa (あ一) and eto (えと). Regarding her delivery, there was some occasional halting in her speech. However, what stand out are the structural errors that interfere with communication, such as shiken ni gōkaku shitara (試験に合格した ら), 'if I will pass the exam,' in line 5. Such errors seriously interfere with communication and the viewer needs subtitles in order to get what she really means in this context.

Especially for nursing jobs, a high level of language communication skill and control of complex medical terminology are required for daily conversation with patients, doctors and co-workers. Even though the JLPT promises "The ability to understand Japanese used in everyday situations (nichijōteki na bamen) and in a variety of circumstances to a certain degree" for N2 level, the Japanese of the foreign medical staff who scored Pre-N2 level of Japanese language is not sufficient to the task (see chapter 1). This prompts the question of the JLPT's validity and accountability. One of the huge weaknesses of JLPT is that the test is not normed. Moreover, it is unclear that the new JLPT can predict the success of 
foreign health care workers. The test attempts to measure language knowledge and the competence required to perform communicative tasks using language knowledge. However, the linguistic competence that is measured in JLPT is not equivalent to what most western scholars understand as "proficiency." The test does not measure skills relevant to the work that health care workers do. And what is more, there is no theoretical framework or underpinning for testing in Japan. Without accountability in language testing, namely, a common metric for language "proficiency," learners can pass the higher grade of the JLPT and still be unable to use the language for some real-world purposes.

An additional obstacle stands in the way of foreign workers' success. Beyond the need for conversational skills, foreign workers face the challenge of professional qualification. In order to work in Japan permanently, the foreign candidates have to pass the national board exam within two or three years, and the exam requires near-native level of Japanese reading skill. The following are sample questions from the national board exam for nurses in fiscal 2010 which were retrieved from the Health Policy Bureau, MHLW. 


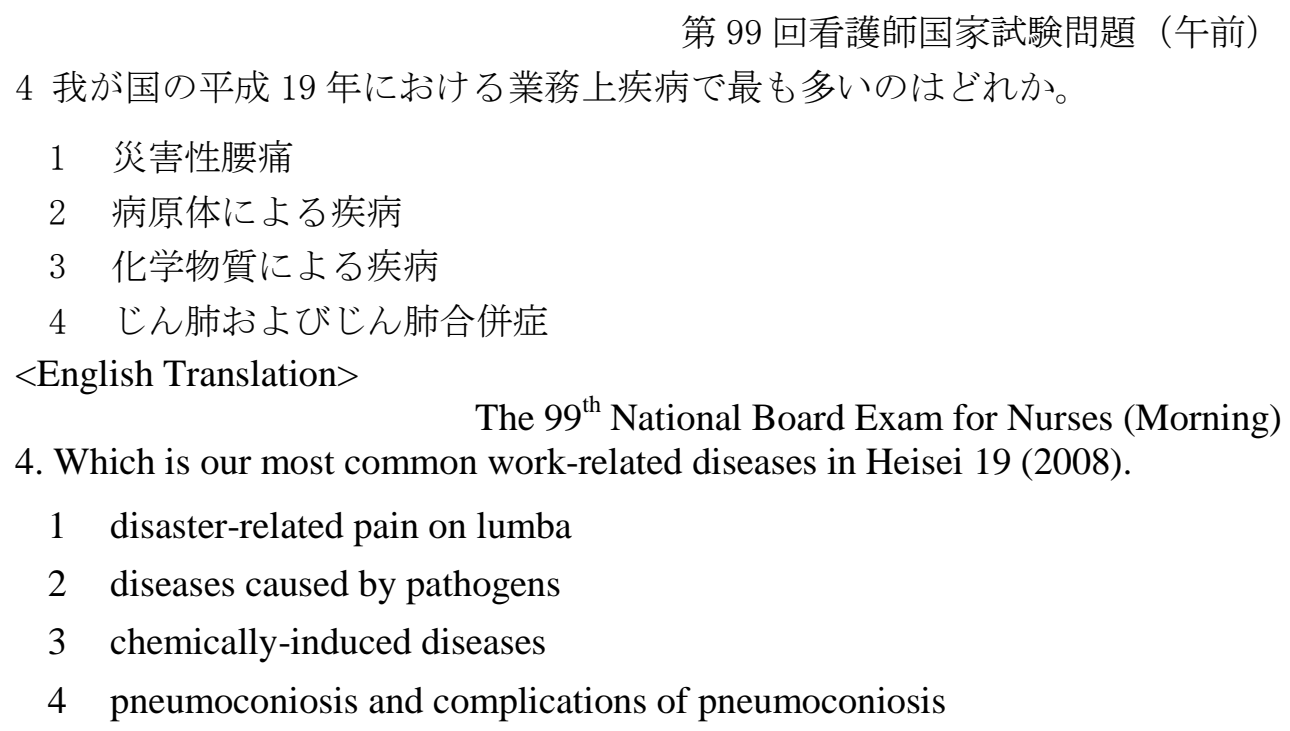

For the national board exam for nurses, no hurigana are provided so that the exam requires the test takers to be able to read and comprehend medical terminology written in Japanese in the process of choosing the right answers from the multiple choice questions. Moreover, understanding Japanese culture is essential. Even though the foreign nurses are experienced licensed nurses in their own countries, it is highly doubtful if they have knowledge about common workrelated diseases in foreign countries. If the test takers are still struggling at this level it makes it more difficult to choose the correct answer. The exam requires a fairly high level of Japanese reading skill and broad work-related knowledge of the test takers. 


$$
\begin{aligned}
& \text { 第 } 99 \text { 回看護師国家試験問題（午後） } \\
& 27 \text { 栄養素と消化酵素の組合せで正しいのはどれか } \\
& 1 \text { 炭水化物——リパーゼ } \\
& 2 \text { 蛋白質 —ーリプシン } \\
& 3 \text { 脂肪 —マルターゼ } \\
& 4 \text { ビタミン——アミノペプチターゼ } \\
& <\text { English Translation> } \\
& \text { The } 99^{\text {th }} \text { National Board Exam for Nurses (Afternoon) } \\
& \text { 27. Which is the correct combination between nutrition and digestive enzyme? } \\
& 1 \text { carbohydrate---lipase } \\
& 2 \text { protein---trypsin } \\
& 3 \text { fat---maltase } \\
& 4 \text { vitamin---aminopeptidase }
\end{aligned}
$$

Another challenge among non-native speakers is loanwords (katakana)—words which are borrowed from foreign languages and pronounced according to Japanese phonological patterning. For example, リパーゼ/ripāze/ is a loan word whose pronunciation is borrowed from German (English: lipase); トリ プシン/toripusin/ (trypsin); マルターゼ/marutāze/ (maltase); ビタミン/bitamin/ (vitamin); アミノペプシターゼ/amino pepushitāze/ (aminopeptidase) are other examples. Such loanwords pose a perennial challenge to non-native Japanese speakers.

In this era of globalization, what kind of language ability should be measured and who measures language ability for what kind of purposes should be a matter of serious concern. There is a "culture of examinations" in Japan. The examinations which measure a test taker's depth of knowledge are primarily a process of elimination. In order to have foreign workers integrate into Japanese speaking 
society, the Japanese government has established serious hurdles for them to overcome and host residents expect the same level of language ability as Japanese native speakers have. But if the foreign candidates for nurses and care workers cannot understand the question of the exam, it is impossible to pass it and stay in Japan as a certified nurse or caregiver. As a measurement tool of language ability for foreign nurses and caregivers, the JLPT level 2 (current N2 level) fail to predict their success. There is a significant gap of expectation toward the foreign nurses and caregivers' language skill between the Japanese government who set up the language minimal language ability for foreign workers and the hospitals or medical institutions which have accepted the foreign nurses and caregivers. A test which measures what a speaker can do in terms of everyday language rather that what a speaker has studied or learned is urgently needed.

\subsection{Western approaches to proficiency: ACTFL-OPI and CEFR}

One of the huge weaknesses of JLPT is that it is not build on a theoretical foundation that defines proficiency. This section examines two western assessment tools: the American Council on the Teaching Foreign Languages (ACTFL) Oral Proficiency Interview (OPI) ${ }^{16}$ and the Common European Framework of Reference for Languages: Learning, Teaching, Assessment (CEFR).

\footnotetext{
${ }^{16}$ For purposes here, this thesis will focus on the ACTFL-OPI because it is the best know in Japan and longest established.
} 


\subsubsection{ACTFL-OPI}

Central to the development of renewed interest in testing language proficiency and language teaching in the United States is "the Proficiency Movement," primarily represented by ACTFL. The ACTFL Proficiency Guidelines for listening, speaking, reading and writing have been institutionalized in foreign language professional circles since the 1980's. In April 1978, President Jimmy Carter's commission on Foreign Language and International Studies (1979) recommended the establishment of "language achievement goals for the end of each year of study with special attention to speaking proficiency" (P.15). With the publication of the ACTFL Provisional Proficiency Guidelines, later the ACTFL Proficiency Guidelines, and the ACTFL Oral Proficiency Interview (OPI) in 1982, the proficiency movement began. According to Liskin-Gasparro (2003), the ACTFL Proficiency

Guidelines and the OPI are based on a rating scale and an assessment procedure originally developed in the 1950 s by the Foreign Service Institute of the U.S. Department of State and Interagency Language Roundtable (ILR). Both called for the creation of criteria that could be used to identify the foreign language proficiency of U.S. government employees. The original government guidelines were effectively demonstrated tools and standards for assessment of speaking ability; however, they were neither practical nor achievable for K-12 or college/university instruction. The result of collaboration between U.S. government testing agencies, ACTFL, and the 
Education Testing Service (ETS), the ACTFL Provisional Proficiency

Guidelines "brought to academic foreign language professionals a framework for understanding and measuring oral language ability that served as a catalyst for research, teaching, testing, and curriculum development project" (LiskinGasparro, 2003, P.483). At present, the speaking scale is widely used in the United States (at both the state and national level) in order to measure language proficiency.

The ACTFL OPI assesses a learner/speaker's proficiency—the ability to do something with the language —not one's achievement—a measure of what an individual has learned through classroom instruction. Grammatical accuracy is only one component of knowledge that native speakers possess.

The modern competence-performance distinction—one's implicit or explicit knowledge of system of the language, one's actual production and comprehension of language in specific instances of language use (Chomsky, 1965; Hymes, 1972)—served as the basis for the work of many other researchers beginning in the 1970's. Hymes (1972) among others (Cf. Gumperz, 1964; Labov, 1966) brought the sociolinguistic perspective, appropriate use of knowledge in contextual communicative language into the discussion. Hymes proposed a broader and more realistic notion of competence, namely, "communicative competence" not only as inherent grammatical competence but also as the ability to use grammatical competence in a variety 
of communicative situations, such as knowledge of language functions, or illocutionary acts and of sociolinguistic conventions.

As for ACTFL, a learner/speaker's language ability to perform various tasks in a realistic setting is determined by an oral interview. In the ACTFL Oral Proficiency Interview Tester Training Manual (1999), levels of proficiency (Novice, Intermediate, Advanced and Superior, with plus values for the lower three) are distinguished by considering the four interrelated assessment criteria underlying the proficiency description: "global tasks and functions," "context and content," "accuracy" and "text type" (as cited in Omaggio, 2002). "Global tasks and functions" refers to real-world tasks that the speaker performs with language. As one's proficiency increases, the complexity of the language which is used to accomplish real world tasks also increases. Typically, speakers rated as Novice, the lowest level of scale, can list up various items or phrases. In the intermediate range, speakers can create with language by responding and answering simple questions. Advanced speakers are capable of paragraph-length description and narration. At the highest range of proficiency, Superior, speakers can develop an argument, support their opinions, and discuss a hypothetical context extensively.

"Context and content" refers to the social context and content areas in which the language can be used. As the levels of proficiency increase, the context of conversation demands more flexibility in order to deal with unpredictable situations. The content at the lower levels tends to center on 
personal autobiographical information, experiences and interests, which allows the interviewee to stay in present tense and deal with concrete rather than abstract context. On the other hand, at the higher levels of proficiency the range of content that the speaker can discuss is wide and rather abstract.

"Accuracy" refers to acceptability, quality and precision of the message conveyed, features which define how well the speaker performs the task pertinent to those contexts and content areas. Therefore, accuracy includes every single aspect of fluency, grammar, pronunciation, vocabulary, pragmatic competence, and sociolinguistic competence. Since higher levels of proficiency are always associated with abstract content, they require more refined, elaborated use of lexical and pragmatic language.

"Text type" refers to the quality and the organizational aspects of language produced. Text type develops from words or phrases to an organized and sequenced discourse.

\begin{tabular}{|lllll|}
\hline $\begin{array}{l}\text { Proficiency } \\
\text { Level }\end{array}$ & $\begin{array}{l}\text { Global Tasks \& } \\
\text { Functions }\end{array}$ & Context/Content & Accuracy & $\begin{array}{l}\text { Text } \\
\text { Type }\end{array}$ \\
\hline Superior & $\begin{array}{l}\text { Discuss topics } \\
\text { extensively, support } \\
\text { opinions and } \\
\text { hypothesize. Deal with } \\
\text { a linguistically } \\
\text { unfamiliar situation. }\end{array}$ & $\begin{array}{l}\text { Most formal and } \\
\text { informal settings / } \\
\text { Wide range of } \\
\text { general interest topics } \\
\text { and some special } \\
\text { fields of interest and } \\
\text { expertise. }\end{array}$ & $\begin{array}{l}\text { No patterns of errors in } \\
\text { basic structures. Errors } \\
\text { virtually never interfere } \\
\text { with communication or } \\
\text { distract the native } \\
\text { speaker from the } \\
\text { message. }\end{array}$ \\
\end{tabular}




\begin{tabular}{|c|c|c|c|c|}
\hline Advanced & $\begin{array}{l}\text { Narrate and describe in } \\
\text { major time frames and } \\
\text { deal effectively with an } \\
\text { unanticipated } \\
\text { complication. }\end{array}$ & $\begin{array}{l}\text { Most informal and } \\
\text { some formal settings / } \\
\text { Topics of personal } \\
\text { and general interest. }\end{array}$ & $\begin{array}{l}\text { Understood without } \\
\text { unaccustomed to } \\
\text { dealing with non-native } \\
\text { speakers. }\end{array}$ & Paragraphs \\
\hline Intermediate & $\begin{array}{l}\text { Create with language, } \\
\text { initiate, maintain, and } \\
\text { bring to a close simple } \\
\text { conversations by } \\
\text { asking and responding } \\
\text { to simple questions. }\end{array}$ & $\begin{array}{l}\text { Some informal } \\
\text { settings and a limited } \\
\text { number of } \\
\text { transactional } \\
\text { situations / } \\
\text { Predictable, familiar } \\
\text { topics related to daily } \\
\text { activities. }\end{array}$ & $\begin{array}{l}\text { Understood, with some } \\
\text { repetition, by speakers } \\
\text { accustomed to dealing } \\
\text { with non-native } \\
\text { speakers. }\end{array}$ & $\begin{array}{l}\text { Discrete } \\
\text { sentences }\end{array}$ \\
\hline Novice & $\begin{array}{l}\text { Communicate } \\
\text { minimally with } \\
\text { formulaic and rote } \\
\text { utterances, lists and } \\
\text { phrases. }\end{array}$ & $\begin{array}{l}\text { Most common } \\
\text { informal settings / } \\
\text { Most common } \\
\text { aspects of daily life. }\end{array}$ & $\begin{array}{l}\text { May be difficult to } \\
\text { understand, even for } \\
\text { speakers accustomed to } \\
\text { dealing with non-native } \\
\text { speakers. }\end{array}$ & $\begin{array}{l}\text { Individual } \\
\text { words and } \\
\text { phrases }\end{array}$ \\
\hline
\end{tabular}

Table 2.2.1-1. ACTFL Assessment Criteria: Speaking Proficiency. (Source: Swender 1999, p.31 (as cited in Omaggio, 2002, P.14)).

An alternative view of proficiency is offered by Canale and Swain (1980). Reviewing and evaluating the various theoretical perspectives on competence and performance that had been articulated in response to the modern approach to proficiency, they formulate a theoretical framework for communicative competence which consists of four major components: “grammatical competence," “sociolinguistic competence," “discourse competence," and "strategic competence." In their frame work, "grammatical competence" refers to mastery of the linguistic code (verbal or non-verbal) to include vocabulary knowledge as well as knowledge of morphological, syntactic, semantic, phonetic and orthographic rules. "Sociolinguistic competence" addresses knowledge of rules and conventions which underlie comprehension and language use in a variety of social situations. "Discourse 
competence" involves the ability to combine forms and meanings to achieve cohesion in form and coherence in thought, which help to link individual sentences and utterances to a structural whole. "Strategic competence" is concerned with knowledge of verbal and non-verbal communication strategies which compensate for breakdowns in communication due to a learner's insufficient knowledge, and performance factors such as paraphrase, circumlocution, repetition, reluctance, avoidance of words, structures or themes, guessing, changes of register and style, modifications of messages and so on.

More recently, taking into consideration of the result of prior theoretical and empirical research, Bachman (1990) proposes a model of communicative competence more precisely: "communicative language ability" (which is slightly altered by Bachman and Palmer (1996)). According to Bachman and Palmer's model, "language knowledge" consists of two main components: “organizational knowledge” and "pragmatic knowledge." The first, “organizational knowledge," relates to knowledge controlling the formal structure of language, i.e. "grammatical knowledge" (control of vocabulary, morphology, syntax, phonology, and graphology), and knowledge of conventions for combining sentences or utterances into texts, i.e. "textual knowledge" which enables comprehension and production (cohesion, rhetorical and conversational organization, and imaginative functions). The second, "pragmatic knowledge," relates to the knowledge of how to express 
acceptable language functions and for interpreting the illocutionary power of utterances or discourse, i.e. "functional knowledge" (ideational functions, manipulative functions, heuristic functions, and cultural references and figures of speech) and knowledge of sociolinguistic conventions for creating and interpreting appropriate language utterances in a particular context of language use, i.e. "sociolinguistic knowledge" (dialects and language varieties, registers, and natural and idiomatic expressions). Thus, communicative language competence is organized in four main categories: grammatical knowledge, textual knowledge, functional knowledge, and sociolinguistic knowledge. (See Figure 2.2.1-2.)

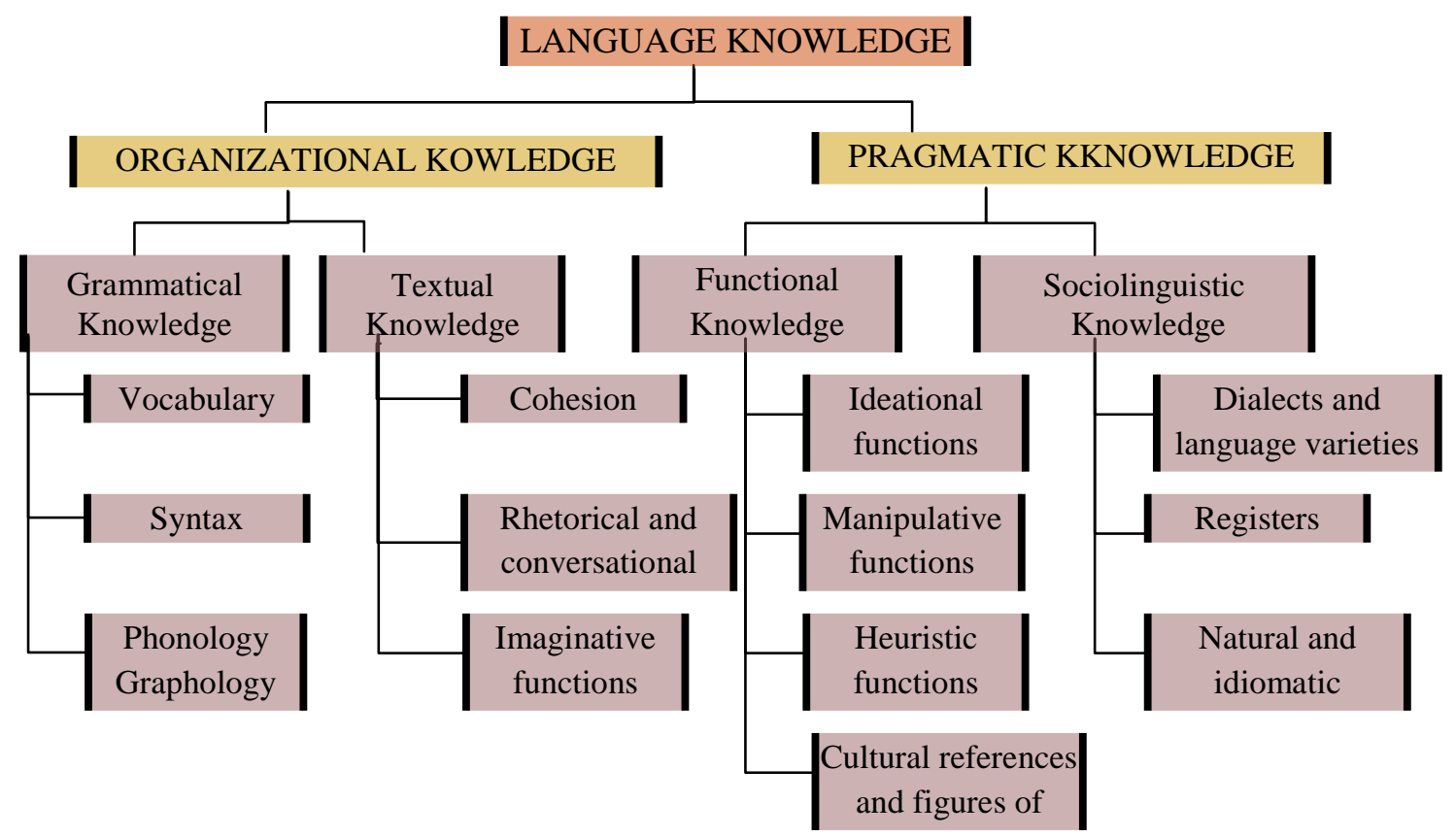

2.2.1-2. Areas of language knowledge (Bachman and Palmer, 1996, p.68)

Clearly, objections can be raised about the ACTFL guidelines. Communicative competence is measured on a hierarchical scale within the 
context of these four assessment criteria. Bachman and Savignon (1986) point out the lack of empirical foundation for the guidelines and question the appropriateness of adapting settings and context that university students may not be familiar with. Also, some terms in the rating scale, such as "discourse," "interactive," or "communicative" strategies are not well-defined. These terms which discriminate between the students at the proposed ability levels, are not confirmed empirically. On instrumental grounds, Iwasaki (2002) observes that the test must be delivered by a trained OPI interviewer and is a timeconsuming one-on-one interview-both of which are drains on resources. On the teaching side, the assessment criteria seem less useful as a tool to measure progress of Japanese language ability, especially at the lower levels (Eda, 2008). With all its weakness, this author believes that ACTFL could be useful for rating and comparing learner outcomes as a proficiency test that is not based on a prescribed curriculum—namely for immigrants who have various learning backgrounds. The assessment criteria reflect the real language demands of daily life, and enable us to measure what the speaker can do in terms of language. Although these notions leave room for discussion and ACTFL OPI needs improvement, the assessment criteria give fresh insights into the evaluation of language proficiency. 


\subsubsection{CEFR}

The CEFR is probably one of the most influential projects in the field of language teaching and learning in Europe. Following the recommendation of an intergovernmental symposium "Transparency and Coherence in Language Learning in Europe" hosted by Switzerland and coordinated by Eurocentres at Rüschlikon in November 1991, the CEFR was developed between 1993 and 1996 by the Council of Europe International Working Party (North, 2006). Threshold projects were launched in order to identify and describe the kinds of language proficiency needed by European citizens to interact and co-operate effectively. Simultaneously, there were other influential initiatives in the development of the CEFR, such as work on learner autonomy and vocational language learning (Figueras, North, Takala, Verhelst, and Van Avermaet, 2005). The CEFR is a standard, international scale of levels for language learning which has changed how foreign languages are taught and learned in Europe; it provides descriptors of what learners should be able to do in terms of language.

The CEFR views users and learners of a language as "members of society who wish to accomplish tasks in a given set of circumstances (p.1)," and the Descriptive Scheme and the Common Reference Levels have been developed so as to be able to measure a learner's progress at each stage of learning and on a life-long basis (Council of Europe, 2001). According to De Jong (2004), the intended comprehensiveness of the CEFR is reflected in two dimensions: a 
qualitative and a quantitative dimension. The former refers to a taxonomy or descriptive system of language activities—general range and vocabulary range, accuracy, fluency, interaction, and coherence-whereas the latter refers to different levels of language competence-vocabulary range, vocabulary control, grammatical accuracy, phonological control, orthographic control, sociolinguistic appropriateness, flexibility, turn-taking, thematic development, coherence and cohesion, spoken fluency, and propositional precision (Council of Europe, 2001). In the descriptive system, six main categories are distinguished in a $3 \times 2$ set-up: reception, production, and interaction in the modes 'spoken' and 'written.' The CEFR defines second language (L2) proficiency in three broad bands, each of which is further subdivided to yield six levels: A1, A2; B1, B2; C1, C2 (A1 being the most basic and $\mathrm{C} 2$ the most advanced). Overall proficiency is then summarized in relation to five communicative skills-listening, reading, spoken interaction, spoken production, and writing. 


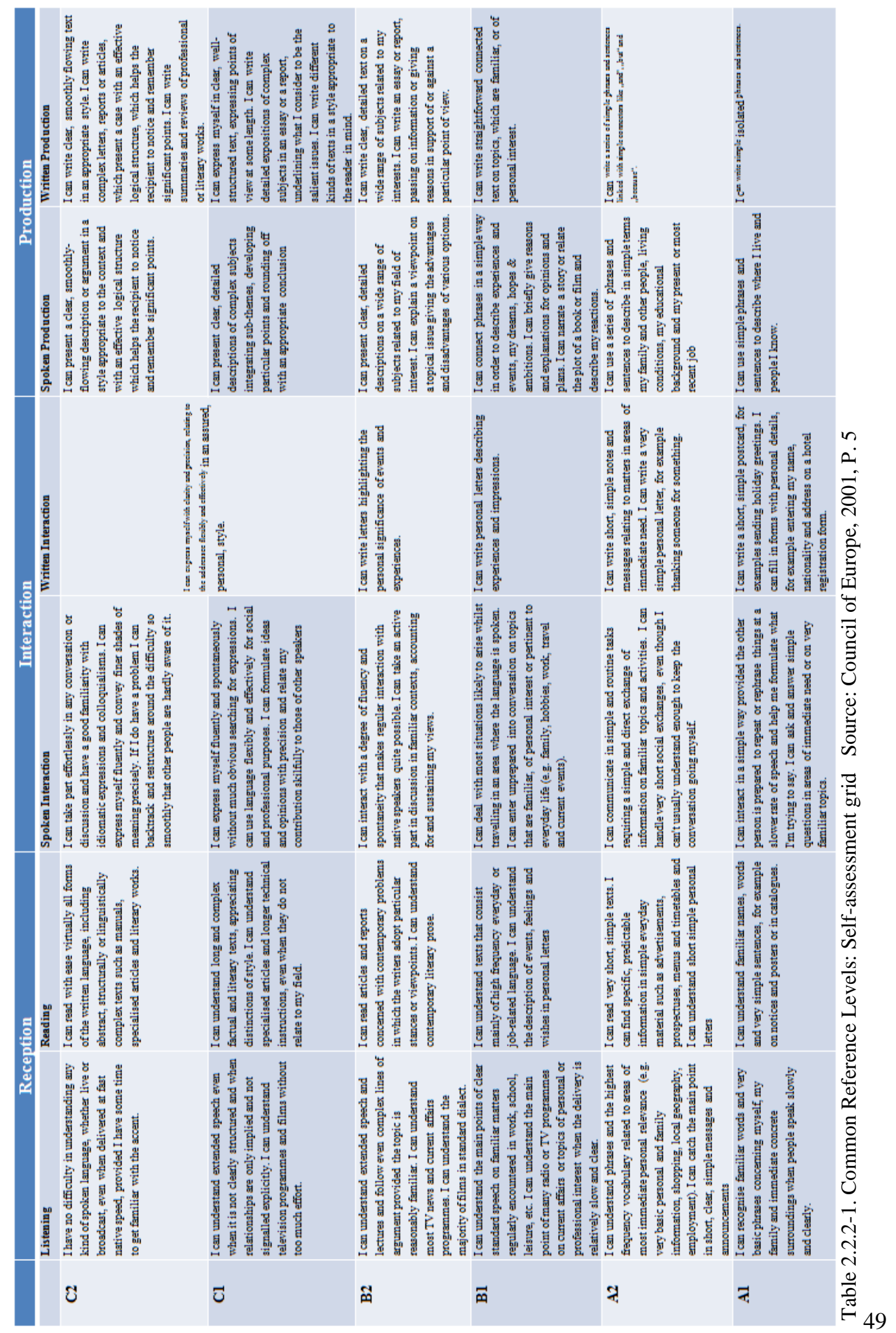


Each of these six cells is further subdivided in to 34 activity-based illustrative scales. These include 'listening as a member of a live audience,' 'reading correspondence,' 'taking the floor in conversation/discussion,' and so forth. The core of the scheme is a set of communicative language activities and descriptors mainly taking the form of 'can-do' statements: C2 can give clear, smoothly flowing, elaborate and often memorable descriptions (sustained monologue: describing experience); C1can deliver announcements fluently, almost effortlessly, using stress and intonation to convey finer shades of meaning precisely (public announcement); B2 can write an essay or report which develops an argument, giving reasons in support of or against a particular point of view and explaining the advantages and disadvantages of various options (reports and essays); B1can understand simple technical information, such as operating instructions for everyday equipment and can follow detailed directions (listening to an announcements and instructions); A2 can identify specific information in simpler written material such as letters, brochures and short newspaper articles describing events (reading for information and argument); A1can ask people for things and give people things and can handle numbers, quantities, cost and time (transactions to obtain goods and services).

The CEFR is intended as a reference document for language curriculum and syllabus development, textbook writing, teacher training, as well as assessment (North, 2000). The application of the common proficiency scale 
assessing student performance and designing syllabi and curricula in educational settings has major consequences. Thus, the creation of models of proficiency has been sparking lively critical discussion.

In sum, one of the serious limitations of the new JLPT is its failure to recognize the importance of the full context of language use. Although the new JLPT promises more focus on communicative linguistic competence, since it is a written multiple-choice exam, it is difficult to see how it measures the examinees' productive skills (speaking and writing), or what they can perform in terms of language. Compared to these two assessments above, the existing most influential Japanese language proficiency test in Japan, the JLPT, lacks credibility for measuring linguistic proficiency for real world purposes. On the teaching side, achievement tests like the JLPT which measure what the students learned in a given curriculum are useful in order to keep track of their mastery of a certain body of material (vocabulary, grammar, kanji etc.). However, according to the definition of language proficiency, this kind of achievement knowledge is not necessarily connected to what speakers can do in terms of using language in a speech community. The JLPT has a significant influence on approaches to framing Japanese language teaching policy because it is viewed as a prominent means to measure and certify Japanese language ability. It sets out to provide a common basis for the elaboration of language syllabi, curriculum guidelines, and textbooks. Establishing professional standards, accountability, and a common metric for measuring language 
proficiency are urgent business in the era of globalization. Doubts about the adequacy of the current JLPT as an assessment framework of foreigners' language proficiency should be raised immediately.

This author concludes that ACTFL OPI and the CEFR-like test are more reliable in measuring a speaker's proficiency-what the speaker can perform and accomplish real-world task in terms of language. The identification of the kind of language proficiency needed by Japanese citizens to interact and cooperate effectively, describing them as accurately and usefully as possible, and ranking of illocutionary acts in terms of appropriateness and level, for example, are all extremely complex. The intentions and objectives of the proficiency movement in the United States and Europe are laudable and give explicit insight for future development of assessment tools for language proficiency in Japan. 
Conclusion

This thesis discussed the acceptance of foreign nurses and caregivers under the scheme of the bilateral Economic Partnership Agreements (EPA), especially in terms of language. In the context of demographic change - a rapidly aging and dwindling population along with a view of itself as a racially and culturally homogeneous country-Japan faces the urgent necessity to import labor from foreign countries. Japan has been seeking a way to accept foreign skilled workers efficiently and succeeded in launching a new policy to import more foreigners "efficiently" under EPAs. Since August 2008, 686 candidates for nurses and care workers have entered Japan from Indonesia and 1,114 from the Philippines; however only 3 of the candidates for nurses have passed the national board exam for nurses so far. Once medical staff under the EPAs start to work, they are required to pass national exams, within three years for nurses and four years for certified care workers, and if they fail, they have to return home. Most of the foreign medical staff are struggling with Japanese language and this raises questions about Japan's language requirement.

In order for visiting workers to pass the national board exam and work as certified medical staff in Japan permanently, the Japanese host residents require quite a high level of language ability in addition to knowledge of their field, i.e. the foreign medical candidates have to pass the same national board exam as native Japanese which includes medical terms in kanji and katakana. There is a fear among the sending countries that Japan is only seeking a way to bring in a foreign work force for a short term. That is, Japan does not require any specified language ability in order to 
participate in the program under the EPAs; however, it actually requires quite a high and arbitrary level of Japanese language in order to obtain the right to stay in Japan permanently. The current paradigm which is essentially "up-or-out" should be reviewed and replaced. The EPA condition for nurses is that they are licensed in Indonesia and have more than two years' experience. Most of the foreign medical candidates started Japanese language learning after they were accepted under the EPAs. Even though they undergo the 6 months of Japanese language training set up for them, research reveals that it was not enough.

Obstacles to success include: the foreign medical staff work full-time, and do not have sufficient time to study Japanese language; most of the foreign workers start Japanese language study after they are accepted under the EPAs; furthermore, the 6 months of Japanese language training set up for them is not enough; and finally, the testing instrument (the JLPT) does not address "proficiency" in a meaningful way. Without the appropriate level of language for foreign workers who wish to work in Japanese speaking society, or clear proficiency guidelines for Japanese language, it is essentially impossible for the host organization to assess the applicants' true language ability and predict their social, economic or professional success. One of the huge weaknesses of JLPT is that the test is not normed. The test attempts to measure language knowledge and the competence required to perform communicative tasks using language knowledge. However, the linguistic competence that is measured in JLPT is not equivalent to what most western scholars understand as "proficiency." What is more, there is no theoretical framework or underpinning for testing in Japan. 
Without accountability in language testing, namely, a common metric for language "proficiency," learners can pass the higher grade of the JLPT and still be unable to use the language for real world purposes. In 2008, three certified care workers from Indonesia demonstrated Japanese language ability at the JLPT Level Two exempting them from Japanese language training. Those who pass at the $\mathrm{N} 2$ level in the new test, which corresponds to the same level in the old test, have demonstrated the ability "to understand Japanese used in everyday situations (nichijōteki na bamen) and in a variety of circumstances to a certain degree." However, now we are facing the fact that foreign medical workers who are supposed to obtain the minimum language ability, are still struggling with everyday conversation with their co-workers. The following abilities are required in order to work in the medical field: reading and writing work-related documents such as nurse/care worker's notes, and communicating (listening and speaking) with co-workers and patients without critical errors interfering with communications or distracting the native speaker from the message.

The acceptance of health care workers from foreign countries will influence traditional values and preferences, affecting priorities and transforming the nation's goals. Since the host residents expect a high level of Japanese language ability of foreign workers, the Japanese government has to make a clearer policy about the language requirement and provide Japanese language training to the foreign labor force. The pedagogy of Japanese language teaching for those whose national language is not Japanese as well the evaluation for Japanese language ability are new challenges 
required in this era of globalization. This thesis reveals that the JLPT fails to predict the social, economic or professional success of foreign health care workers. The JLPT is seriously lacking as an assessment instrument, and Japan faces the urgent need to establish professional standards, accountability, and a common metric for measuring language proficiency. In order to measure true language proficiency, what individuals can do in terms of language, the intentions and objections of the proficiency movement in the United States, i.e. the ACTFL Proficiency Guidelines, and Europe, i.e. the CEFR, are laudable and give explicit insight for future development of assessment tools for language proficiency in Japan. This thesis analyzes the problems inherent in the JLPT and the urgent necessity for a more comprehensible definition of proficiency in Japanese language-the identification of the kind of language proficiency needed by Japanese citizens to interact and co-operate effectively describing it as accurately and usefully as possible, and ranking of illocutionary acts in terms of appropriateness and level.

Also, regarding the acceptance of foreign medical workers under the scheme of EPAs, the related ministries and agencies such as Ministry for Health, Labour and Welfare, Ministry of Foreign Affairs, and Agency for Cultural Affairs, and institutions such as the Association for Overseas Technical Scholarship lack the solidarity required for dealing with the issues. Since the program lacks a coordinator who sees the whole picture, the boundaries of responsibility are unclear. As a result, the related ministries and institutions leave all the responsibilities, such as language teaching, livelihood support, preparation for the national board exam and so on, to the host 
organizations. In order to protect the basic human rights of foreign residents in Japan, the country needs a better system to support foreign residents in Japan.

Like the rest of the developed nations all over the world, Japan is facing a particularly sensitive moment. Unlike the other immigrant nations such as the United States and Australia, there is a strong myth in Japan that the country is racially and culturally homogeneous, which paralyzes the ability to face up to reality, or deteriorate a step to institute a more coherent immigration policies. The problem is that Japan has yet to take a formal stand on the issue. The country does not have coherent immigration policy and is always one step behind, setting up ad-hoc policies to deal with the issues raised under the context of the global society. It is essential to institute a more coherent immigration policy at first place. Still it is unsure whether government will fully open its labor market and choose to become an immigrant nation. (This thesis does not go into detail regarding this.) Japan has other options such as accepting foreign labor force "temporarily," launching a new policy such as EPAs; not accepting foreign labor force which could result in the economic harm caused by population decline; not accepting foreign labor force and using more female and elderly workers; improving their working environment; and the use of new technology for higher labor productivity. However, as a case study taking the acceptance of foreign medical staff under the scheme of EPAs as Japan's first step toward the healthcare migration, it is worth reconsidering the current immigration policy, especially in terms of language, and the actual problems arising from this program. In conclusion, this thesis proposes the urgent need for a more coherent 
approach to immigration policy in terms of language and the development of assessment tools for measuring language proficiency that are built on a theoretical foundation which defines proficiency properly as well as language training. 


\section{Reference}

Agency of Cultural Affairs. (2009). 常用漢字表 [The list of jōyō kanji]. Retrieved from http://www.bunka.go.jp/kokugo/pdf/jyouyou_kanjihyou.pdf. Accessed 9.23.10.

Association of Oversea Technical Scholarship. (2009). 日・インドネシア経済連携協 定に基づく看護師・介護福祉士候補者の受け入れに際し AOTS が担当す る日本語等研修の終了について [The completion of Japanese language training (etc.) by AOTS for JIEPA potential nurses and care workers]. Retrieved from http://www.aots.or.jp/jp/kikanshi/pdf/316_07.pdf Accessed 09.30.09.

Asahi Shimbun. (2009, Nov. 2). 国家試験、言葉の壁訴え 外国人看護師ら受け入 れ施設[National Board Exam, Language Barrier Host institution of foreign nurses (and caregivers) ]. Asahi Simbun. Retrieved from http://www.asahi.com/national/update/1102/OSK200911010119.html . Access 11.28.09.

Bachman, L. F. (1990). Fundamental considerations in language testing. Oxford: Oxford University Press.

Bachman, L.F., \& Palmer, A.S. (1996). Language testing in practice: designing and developing useful language tests. Oxford: Oxford University Press. 
Bachman, L. F. \& Sandra J. Savignon. S. J. (1986). The Evaluation of communicative language proficiency: A critique of the ACTFL oral interview. The Modern Language Journal, 70(4), 380-390

Cabinet Office, Government of Japan. (2004). 外国人労働者受入れに関する世論調 査 [National survey on accepting foreign workers]. Retrieved from http://www8.cao.go.jp/survey/h16/h16-foreignerworker/index.html. Accesses 10.31.09.

Canale, M., \& Swain, M. (1980). Theoretical bases of communicative approaches to second language teaching and testing. Applied Linguistics, 1, 1-47.

Care Work Foundation. (2009). 平成20年度介護労働実態調査 [Survey on actual working condition of certified care workers in fiscal 2008]. Retrieved from http://www.kaigo-center.or.jp/report/h20_chousa_01.html. Accessed 11.18.09. Chomsky, N. (1965). Aspects of the theory of syntax. Massachusetts: The M.I.T. Press. Council of Europe. (2001). Common European framework of reference for languages: learning, teaching, assessment. Cambridge: Cambridge University Press.

Eda, S. (2008). The Japanese skills test as an on-demand placement test: validity and comparisons and reliability. Foreign Language Annual, 41(2), 218-236.

Gumperz, J. J. (1964). Linguistic and social interaction in two communities. In J. Gumperz and D. Hymes. (Eds.) The ethnography of communication (137-153). Washington: American Anthropologist Association. 
Hatasa, Yukiko. (2002). The effects of differential timing in the introduction of Japanese syllabaries on early second language development in Japanese. Modern Language Journal. 86, 349-367.

Health Policy Bureau, Ministry of Health, Labour and Welfare. (2010a). 第99回看護 師国家試験問題 : 午前 [The $99^{\text {th }}$ national board exam for nurses: morning]. Retrieved from http://www.mhlw.go.jp/topics/2010/04/dl/tp_siken_99_kango_01.pdf. Accessed 9.14.10

----(2010b). 第99回看護師国家試験問題 : 午後 [The $99^{\text {th }}$ national board exam for nurses: afternoon]. Retrieved from http://www.mhlw.go.jp/topics/2010/04/dl/tp_siken_99_kango_03.pdf. Accessed 9.14.10

Hymes, D. H. (1972). On communicative competence. In Pride, J. B., \& Holmes, J. (Eds.), Sociolinguistics (269-293). Baltimore: Penguin Education, Penguin Books Ltd.

International Labour Organization. (2001). News flash-December 2001. Retrieved from http://www.ilo.org/public/english/region/asro/tokyo/newsletr/flash0112.htm. Accessed 10.31.09.

Iwasaki, N. (2002). 日本語能力簡易試験(SPOT)の得点と ACTFL 口頭能力測定 (OPI) のレベルの関係について [The correlation between scores of simple 
performance-oriented test(SPOT) and ACTFL OPI]. 日本語教育 [Japanese language teaching], 114, 100-105.

」『日本語教育』114 号、日本語教育学会.

Japan Foundation. (2009). New Japanese language proficiency guideline: executive summary. Retrieved from http://www.jlpt.jp/e/about/pdf/guidebook_e.pdf. Accessed 2.10.10.

Japan Foundation and Japan Educational Exchanges and Services. (2009). The Japanese language proficiency test. Retrieved from http://www.jlpt.jp/e/index.html. Accessed 12.05.09.

---- (2010). 日本語能力試験 JLPT [Japanese language proficiency test]. Retrieved from http://www.jlpt.jp/index.html. Accessed 9.10.10

Japan International Cooperation of Welfare Services. (2009). 平成 21 年度版 インド ネシア人看護師・介護福祉士受け入れの枠組 [The framework for accepting Indonesian nurses and certified care workers in fiscal 2009]. Retrieved from http://www.jicwels.or.jp/html/h21_Indonesia_pdf/h21_Indonesia_FORM/21in donesia_kango-guideline2.pdf Accessed 10.7. 09.

Japan Nursing Association. (2008a). Statistical data on nursing service in Japan (2007). Retrieved from http://www.nurse.or.jp/jna/english/statistics/index.html. Accessed on 11.27.09. 
---- (2008b). インドネシア人看護師候補生受け入れにあたって一日本看護協会 の見解 [JNA's view toward accepting potential Indonesian nurses.]. Retrieved from http://www.nurse.or.jp/home/opinion/press/2008pdf/0617-4.pdf. Accessed on 10.31.09.

---- (2009). 時間外勤務、夜勤·交代勤務等緊急実態調査 [Emergency investigation for overtime and evening/rotating shift]. Retrieved from http://www.nurse.or.jp/home/opinion/newsrelease/2009pdf/20090427.pdf. Accessed 11.26.09.

Kaneko, M. (2009, Mar. 18). Indonesian caregivers working to adapt. The Japan Times. Retrieved from http://search.japantimes.co.jp/cgibin/nn20090318f1.html. Accessed 12.05.09.

Kaneko, R., Ishikawa, A., Ishii, F., Sasai, T., Iwasawa, M., Mita, F., and Morizumi, R. (2009). Commentary to population projections for Japan: A supplement to report of the 2006 revision. The Japanese Journal of Population, 7(1), 1-46.

Kawakami, I. (2003). 年少者日本語教育における「日本語能力測定」に関寸る 観点と方法 [Fundamental considerations in assessing the Japanese language proficiency of children learning Japanese as a second language]. Waseda journal of Japanese applied linguistics, 2, 1-16.

Lavob, W. (1966). The social stratification of English in New York City. Washington: Center for Applied Linguistics. 
Liskin-Gasparro, J. E. (2003). The ACTFL proficiency guidelines and the oral proficiency interview: A brief history and analysis of their survival. Foreign Language Annual, 36(4), 483-490.

Ministry of Economic, Trade and Industry. (2008). Agreement between Japan and republic of Indonesia for an economic partnership. Retrieved from http://www.mofa.go.jp/region/asia-paci/indonesia/epa0708/agreement.pdf. Accessed 10.31.09.

Ministry of Health, Labour and Welfare. (2009a). Annual Health, Labour and Welfare Report 2007-2008. Retrieved from http://www.mhlw.go.jp/english/wp/wphw2/index.html Accessed 10.31.09.

---- (2009b). 平成20年度 国民基礎生活調査の概要 [Summary of national livelihood survey 2008]. Retrieved from http://www.mhlw.go.jp/toukei/saikin/hw/k-tyosa/k-tyosa08/index.html Accessed 10.26.09.

---- (2009c). 日・インドネシア経済連携協定に基づくインドネシア人看護師・ 介護福祉士候補者の受入れについて[The acceptance of potential nurses and caregivers from Indonesian as a part of EPA.]. http://www.mhlw.go.jp/bunya/koyou/other21/index.html Accessed 9.20.09.

---- (2009d). 平成20年度 雇用動向調査 [Survey on trends in employment in fiscal 2008]. Retrieved from 
http://www.mhlw.go.jp/toukei/itiran/roudou/koyou/doukou/08-2/index.html Accessed 11.22.09.

---- (2009e). 平成20年賃金構造基本統計調査（全国）結果の概況 [Summary of key statistics for national wage structure]. Retrieved from http://www.mhlw.go.jp/toukei/itiran/roudou/chingin/kouzou/z2008/index.html. Accessed 11.27.09.

---- (2009f). 第21回社会福祉士及び介護福祉士国家試験の合格発表について [Announcement of the 21st national exam for social workers and caregivers]. Retrieved from http://www.mhlw.go.jp/houdou/2009/03/h0331-3.html. Accessed 11.28.09. (2010). 第 99 回看護師国家試験における経済連携協定に基づく外国人看護 師候補者の合格者について[ Passer of the $99^{\text {th }}$ national exam for nurses: foreign candidates for nurses under the scheme of Economic Partnership Agreement]. Retrieved from http://www.mhlw.go.jp/stf/houdou/2r98520000005alw.html. Accessed 3.27.10. Ministry of Justice. (2009). 平成21年度版 出入国管理 [2009 immigration control]. http://www.moj.go.jp/NYUKAN/nyukan80-1.pdf. Accessed 11.9.09.

Miyazaki, S., and Nakata, Y. (2008). 看護職員の潜在化と労働条件:看護師不足解 消に向けての論点提案 [The trend of non-working nurses and working conditions: proposal for nurse shortage]. Retrieved from 
http://www.itec.doshisha-u.jp/03_publication/03_policy/08-08-Miyazakiitecpb.pdf. Accessed 11.22.09.

Nakagawa, M. (2009, Nov. 21). 国家試験見直しへ議論 外相、外国人看護師研修 生問題で[Argument for reviewing the national boarding exam; the minister of foreign affair commented on the problem of foreign nurses]. Retrieved from http://www.asahi.com/politics/update/1121/NGY200911210022.html. Accessed 12.05.09.

Nara, H., \& Noda, M. (2003). Acts of reading:exploring connections in pedagogy of Japanese. Honolulu: University of Hawaii Press.

National Institute of Population and Social Security Research. (2009). Population statistics of Japan 2008. Retrieved from http://www.ipss.go.jp/index-e.html. Accessed 10. 26

North, B. (2006). The Common European Framework of Reference: Development, Theoretical and Practical Issues, paper presented at the symposium 'A New Direction in Foreign Language Education: The Potential of the Common European Framework of Reference for Languages', Osaka University of Foreign Studies, Japan, March 2006.

Omaggio, H. A. (2002). Teaching language in context ( $3^{\text {rd }}$ ed.). Boston: Heinle \& Heinle.

President's Commission on Foreign Language and International Studies. (1979). Strength through wisdom: a critique of U.S. capacity. Washington: Government Printing Office. 
Sankei Shimbun. (2009, Jul. 2). 外国人の介護福祉士·看護師 賛成過半数 [Majority supports foreign caregivers and nurses]. Sankei Shimbun. Retrieved from http://sankei.jp.msn.com/life/welfare/090702/wlf0907021802002-n1.htm. Accessed 11.28.09.

Tokawa, T., Miyazaki, S., and Morimoto, M. (2009, Nov. 2). 国家試験、言葉の壁訴 え外国人看護師ら受け入れ施設 [The call for the national boarding exam and language barrier from the host facilities]. Asahi Shimbun. Retrieved from http://www.asahi.com/health/news/OSK200911010119.html. Accessed 12.05.09.

Watanabe, S. (1998). Concurrent validity and application of the ACTFL Oral Proficiency Interview in a Japanese language program. Journal of the Association of Teachers of Japanese,32(1), 22-38.

Yokoyama, N., Kida, M., and Kubota, Y. (2004). 日本語能力試験と OPIの相関関 係による運用力分析-技能バランスに焦点をあてて [The competence analysis of the correlation between JLPT and OPI, focusing on the balance of skills]. Acquisition of Japanese as a second language, 7, 81-99. 


\section{Appendix NHK News whole transcript}

アナウンサー: EPA 経済連携協定に基づいて来日した インドネシア人とフ イリピン人の合わせて 3 人が 今年度の看護師の国家試験にはじめて合格し ました。

合格発表の会場に居合わせた日本人女性:きやー やった イエイ

アナウンサー: EPA に基づき 看護師を目指し 来日しているインドネシア人 とフィリピン人は 合わせて 370 人で 日本の医療機関で働きながら 看護 師資格の取得を目指しています 厚生労働省によりますとこのうち 254 人 が 今年度の国家試験を受験しました

アナウンサー: その結果 おととし来日して 新潟県三条市の病院で働く イ ンドネシア人 2 人と 去年来日して 栃木県足利市の病院で働く フィリピ ン人 1 人の 合わせて 3 人が はじめて合格しました。

リア・アグスティナ: 病院のみなさま えつと あー いろいろななサポート から みなさんのおかげで 私たち が えと 試験に合格したら

Subtitle: 病院の皆様いろんなサポートのおかげで私たちは試験に合格できた アグスティナ: 本当に感謝しています はい どもありがとうございました Subtitle: 本当に感謝しています どうもありがとうございました ヤレド・フェブリアン・フェルナンデス: 死めほど勉強しました

Subtitle [死ぬほど勉強した]

会場: (笑い声)

フェルナンデス: 国家試験 やってきましたよね

女性: 国家試験? 
フェルナンデス:うん あの かっこ(過去)問題もくりかえして やっていき ました

Subtitle[国家試験の過去問題をくり返しやった]

アナウンサー: 今回の試験は 全体の合格率が およそ $90 \%$ だったのに対して EPA に基づいて来日した外国人の合格率は $1 \%$ 余りで ほとんどのひとが 不合格となりました

協定では 日本で看護師として働き続けるためには 来日から 3 年以内に 国家資格を取得しなければならず 難しい漢字の専門用語を 読み書きする 国家試験が 大きな壁になっていると指摘されています

おととし インドネシアから より高度な医療を学ぼうと来日した デヴィ・ セップティヤスリ二さん 2 回目の受験となった今年度の国家試験は 不合格 でした

セップティヤスリニ：ない です 补

かなしいですが

Subtitle [悲しいですね]

えとー 来年のチャンスが ま またありますので その時も 頑張り たいと思います

Subtitle [来年チャンスがまたあるので＼cjkstart頑張りたいと思います]

ガルーダ・サポーターズ 宮崎和加子 共同代表:

受かるほうが 極めてまれで この制度そのものが あのえあ すごく無理 があって 日本語の 力も 多様な力がもとめられますから 日本語の力を まずつけて つけるような方向での 国が支援するべきじやないかなと

アナウンサー: おととし 第一陣として来日したおよそ 100 人のインドネシア 人は 来年度の試験に合格しなければ 帰国せざるを得ないということで 厚生労働省は 今後 受験者の日本語学習を支援していく方針です 


\section{$<$ English translation>}

An anchorman: The total of three Indonesian and Filipino who came to Japan under the scheme of Economic Partnership Programs (EPAs) passed this year's national board exam for nurses for the first time (in this program).

Japanese women at the venue of announcement of test result: Oh my! Yes! Yey!

An anchorman: The total number of Indonesian and Filipino who came to Japan and aspires to becoming nurses under the scheme of EPAs is 370. They aim to obtain the nursing license while working at the medical institution in Japan. According to the Ministry of Health, Labour and Welfare (MHLW), 254 of them took this year's national board exam.

An anchorman: As a result, total of three: two Indonesian who came to Japan two years ago and have worked at a hospital in Sanjyō, Niigata prefecture, and one Filipino who came to Japan last year and have worked at a hospital in Ashikaga, Tochigi prefecture, passed the exam at the first time (in this program).

Ria Agustina: Everyone in the hospital...Uh...er...From various supports...thanks to your help...We...Uh...If we could pass the exam...[I] really appreciate...Yes...Thank you very much.

Subtitle: Everyone in the hospital Thanks to a various support We could have passed the exam I really appreciate it Thank you very much

Yared Febrian Fernandes: I studied to death.

Subtitle: I studied to death

Floor: (laugh)

Fernandes: $[\mathrm{I}]$ have done (studied) the national board exam.

Woman: the national board exam?

Fernandes: Yes. Uh...I have repeated the past test [with foreign accent], too.

Subtitle: I repeated the past test for the national board 
An anchorman: As for this exam, even though the overall average of the passing rate was approximately $90 \%$, that of among the foreign candidates under EPAs was only $1 \%$, which means most of them failed the exam.

According to the EPA condition, foreign candidates for nurses are required to obtain the nursing license within three years in order to keep working in Japan as nurses. It is pointed that the national board exam which requires to read and write the complicated terminology written in kanji poses a significant hurdle to overcome.

Devi Septiyaslini came to Japan two years ago with an ambition to learn higher medical technology. She took this years national board exam for her second trial, but she failed.

Septiyaslini: I don't see (my identification number). It is sad but...

Subtitle: It is sad

Septiyaslini: Um... [I] still have a chance next year, so I would like to do my best then too.

Subtitle: Since I can try next year again, I'd like to do my best.

Wakako Miyazaki a joint representation from the Garuda Supporters: It is extremely rare to have successful candidates (among forein medical staff). This program itself has um a lot of problem. Since a variety of Japanese language ability is required, I think the government should support [them] to improve their Japanese language ability at the first place.

An anchorman: Since the first group of Indonesians who came to Japan two years ago have to go back to their country unless they will pass the national board exam next year, the Ministry of Health, Labour and Welfare plans to support foreign candidates' Japanese language learning. 